\title{
EivF, a factor required for transcription of the adenovirus EIV promoter, binds to an element involved in EIa-dependent activation and cAMP induction
}

\author{
Patricia Cortes, Leonard Buckbinder, M. Aleida Leza, ${ }^{1}$ Nancy Rak, Patrick Hearing, \\ Alejandro Merino, and Danny Reinberg \\ Department of Biochemistry, Robert Wood Johnson Medical School, University of Medicine and Dentistry of New Jersey, \\ Piscataway, New Jersey 08854-5635; 'Department of Microbiology, State University of New York at Stony Brook, Stony \\ Brook, New York 11794 USA
}

\begin{abstract}
The isolation of a cellular factor that was specifically required for transcription from the promoter of the adenovirus early gene iv, an EIa-activated promoter, is described. This factor (EivF) was purified from HeLa cells using a functional transcription assay and identified as a 72,000 - to 65,000 -dalton protein. DNase I footprinting experiments demonstrated that purified EivF bound to the sequence $5^{\prime}$-GT/G/T)ACGT-3' present two times upstream of the Eiv TATA box. Nuclear extracts prepared from HeLa cells contained more than one factor capable of binding to the Eivf recognition site. Previous studies have indicated that a sequence similar to the EivF-binding site was recognized by a 43,000-dalton protein and participated in the cAMP response of the somatostatin promoter. The purified and transcriptionally active EivF also bound to DNA sequence elements present in the somatostatin and $\alpha$-gonadotropin promoters shown previously to be responsive to cAMP.
\end{abstract}

[Key Words: EivF; transcription; cAMP induction]

Received January 19, 1988; revised version accepted June 6, 1988.

The control region for genes transcribed by the RNA polymerase II machinery appears to consist of a complex variety of functional domains of DNA sequences (Breathnach and Chambon 1981; Dynan and Tiian 1985). One of them, the TATA box, is usually located $20-30$ nucleotides upstream from the transcription initiation site (cap site) and appears to position the start site of transcription (Breathnach and Chambon 1981). Previous studies have indicated that at least five protein factors, the so-called general transcription factors, were required for transcription from a promoter that contained the minimum DNA sequence elements (the TATA box and cap site) (Reinberg and Roeder 1987; Reinberg et al. 1987). Other DNA sequence elements important for transcription were found upstream of the TATA box. These upstream elements serve as recognition sites for specific DNA-binding proteins whose roles remain to be elucidated (Dynan and Tiian 1985). It is clear that there are many different upstream promoter elements. Some promoters may contain only one, whereas other promoters have been found to contain many of these elements arranged in mosaic (Dynan and Tjian 1985). Because one particular type of upstream element has been found in a number of different promoters, the same factor may be utilized for the control of expression of different genes (Dynan and Tiian 1985; McKnight and Tjian 1987), or different factors may be able to recognize the same sequence but induce activation from different promoters (Dorn et al. 1987). A third type of control element is the enhancer, which is capable of functioning in an orientation-independent fashion at a great distance from the promoter (Khoury and Gruss 1983).

It thus appears that differential gene expression can be mediated by the interaction of one or many specific transcription factors with critical DNA element|s| present in the promoter and/or the enhancer (Dynan and Tjian 1983a,b; Dynan and Tjian 1985; McKnight and Tjian 1987). This interaction could ultimately result in the activation (Dynan and Tiian 1983a, b; Lee et al. 1987) or repression (Nasmyth et al. 1987) of the expression of a gene. The mosaic arrangement of upstream promoter elements and enhancers suggests that the different specific transcription factors must communicate either directly (by protein-protein interactions) or indirectly (via DNA-mediated interactions), with one another and with those factors that operate by binding to the TATA sequence.

An attractive system that can be used to explore some 
of the mechanisms that operate to control gene expression is the regulation of transcription of the adenovirus early genes by the adenovirus Ela gene products. The EIa transcription unit encodes two polypeptides, p243 and p289, which have identical amino- and carboxy-terminal ends but differ by an internal 46 amino acids that are missing in the smaller polypeptide (Berk and Sharp 1978; Chow et al. 1979; Perricaudet et al. 1979|. p289 was shown to participate in the stimulation of transcription of six adenoviral genes (Gilardi and Perricaudet 1984; Berk 1986; Nevins 1981), as well as some cellular genes (Green et al. 1983; Kao and Nevins 1983; Allan et al. 1984; Stein and Ziff 1984; Svensson and Akusjardi 1984). In most cases, the DNA sequences important for transcription of the EIa-activated promoter are known (for review, see Berk 1986); however, a common regulatory element has not been identified. This is consistent with the observation that the Ela-encoded proteins do not specifically bind DNA.

To gain insight into the molecular and biochemical mechanisms that operate during EIa-mediated activation of the adenovirus early genes, we reconstituted transcription using purified proteins from the adenovirus-encoded Eiv promoter. The Eiv cap site is located 330 nucleotides from the right-hand end of adenovirus DNA; the first 103 nucleotides correspond to the virus inverted terminal repeats. Previous studies have indicated that transcription from this promoter was stimulated by the larger protein encoded by the EIa gene ( $\mathrm{Gi}$ lardi and Perricaudet 1984). Furthermore, it has also been demonstrated that two DNA sequence elements present in the Eiv promoter, one located between positions -239 and -218 and the other between positions -179 and -158 , possessed enhancer-like properties and were involved in the activation process (Gilardi and Perricaudet 1986). In addition, Lee and Green (1987) have shown that a factor present in extracts from uninfected HeLa cells was able to bind to the DNA sequence element present between positions -179 and -158 and to a similar sequence element present immediately upstream of the TATA box.

Montminy and Bilezikjian (1987) have isolated a 43,000-dalton phosphoprotein, from $\mathrm{PCl} 2$ cells, that binds to the cAMP-responsive element present in the somatostatin gene. The sequence recognized by this factor is similar to the repeated motif in the Eiv promoter that has been shown to be important in Ela-mediated activation (Lee and Green 1987). This suggested that transcription from the somatostatin and Eiv promoters may be controlled by the same factor.

In this paper we report the isolation, using a functional transcription assay, of a cellular factor (EivF) that was required specifically to initiate transcription from the Eiv promoter. EivF was shown to be a protein of $72,000-65,000$ daltons. Purified EivF bound specifically to the DNA sequence GT/G/T)ACGT present in the Eiv promoter. Extracts prepared from HeLa cells contained more than one factor that could bind to the EivF recognition. Eivf was also able to bind to elements that had been shown previously to be responsive to cAMP, which were present in the somatostatin and $\alpha$-gonadotropin promoters.

\section{Results \\ Characterization of the cis-acting DNA sequence elements required for transcription from the Eiv promoter}

Previous studies have indicated that DNA sequences starting at the Eiv cap site and extending 240 nucleotides upstream were required for efficient transcription from the Eiv promoter (Gilardi and Perricaudet 1984; Berk 1986). Analysis of the Eiv promoter sequences indicated the presence of two copies of an element that had similarity to the EIa enhancer core sequences defined previously (Hearing and Shenk 1983), three copies of a $5^{\prime}$-GT/G/T)ACG/T/A)-3' heptanucleotide (one within each of the EIa enhancer core sequences and one immediately upstream of the TATA box l, and two Spl-binding sites (Dynan and Tjian 1983b). These elements are organized as indicated in Figure 1A. To assess the role of these various DNA sequence elements during transcription from the Eiv promoter, we studied the transcriptional template activity of various deletions of the Eiv promoter using a HeLa cell nuclear extract as a source of transcription factors. Removal of sequences from the left up to -195 (including the ITR element and an Splbinding site) had no effect on Eiv transcription (Fig. 1B). A gradual decrease of transcriptional template activity was observed upon deletion of each of the EIa enhancer core elements (Fig. 1B). Further deletions to -62 had no effect; however, removal of the sequences between -62 and -46 decreased activity further, and transcription was abolished by the deletion of the TATA box (Fig. 1B). These results suggested that the EIa enhancer elements and sequences between -62 and -46 were required, in addition to the TATA box, for optimal transcription from the Eiv promoter in vitro.

Previous studies have demonstrated that the Eiv promoter was activated by EIa (Gilardi and Perricaudet 1984) and the sequences upstream of -160 were important in this process /Gilardi and Perricaudet 1986; Lee and Green 1987; Handa and Sharp 1984; Hanaka et al. 1987). This was confirmed by the demonstration that the ability of the Eiv promoter deletion mutant DNAs to drive expression of the bacterial chloramphenicol acetyltransferase (CAT) gene, as assayed by a transient expression assay in transfected HeLa cells, was dependent on cotransfection of the Ela gene (Table 1). Maximal activation required the ITR; deletion of these sequences resulted in a threefold decrease in CAT activity (Table 1). Ela-mediated activation of a promoter that did not possess the ITR required the distal Ela enhancer core sequences for maximal activity (see Fig. 1). Deletion of this element caused a 2.5 -fold decrease in activation, as well as a 3 -fold decrease in basal levels of transcription (in the absence of EIa). Deletion of the proximal EIa enhancer core element affected basal levels of transcription but did not affect EIa-mediated activation (Table 1). The 

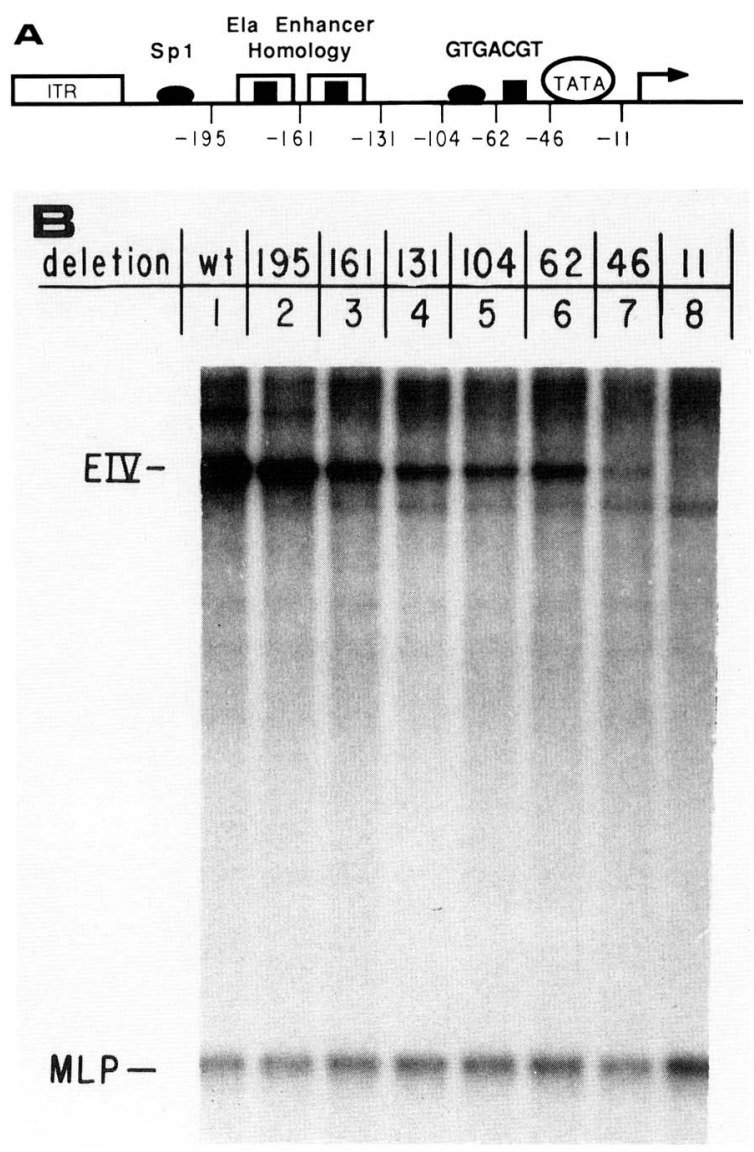

Figure 1. (A) Schematic representation of the different elements of the Eiv promoter. The GT/G/T)ACG(T/A) sequence is represent by solid squares. Solid ovals represent Spl-binding sites. Open squares represent the EIa enhancer core sequence. (B) Transcriptional template activity of various deletions of the Eiv promoter in $\mathrm{HeLa}$ cell nuclear extracts. DNA containing the wild-type Eiv promoter or the different deletions $(0.2 \mu \mathrm{g})$, as indicated at the top, were mixed with a control DNA carrying the Ad-MLP $(0.2 \mu \mathrm{g})$ and with HeLa cell nuclear extract $(90 \mu \mathrm{g})$. Reactions were incubated under transcription conditions, as described in Experimental procedures, and the products separated by electrophoresis on polyacrylamide-urea gels.

removal of sequences between -131 and -104 (a GTrich region/ reduced Ela-mediated induction further. The removal of the Sp1-binding site located at position -100 abolished activation (Table 1).

These results suggested that the ITR sequence, the distal EIa enhancer core element, and sequences present downstream of -130 were involved in activation. Furthermore, they also indicated that the proximal (relative to the cap site) EIa enhancer core sequence had no effect on Ela-mediated activation. Previous studies did not detect an effect on Ela-mediated activation by sequences downstream of -158 (Gilardi and Perricaudet 1984, 1986; Lee and Green 1987). These differences could be attributed to the differential sensitivities of the assays employed.

\section{Purification of a factor specifically required for transcription from the Eiv promoter}

The mechanism(s) by which Ela mediates activation is not clear. It appears that the EIa proteins do not directly recognize specific DNA sequences in the inducible genes (Nevins 1981; Berk 1986). Thus, it has been suggested that EIa acts indirectly by modifying preexisting cellular factors (Nevins 1981; Kovesdi 1986). To gain insight into the mechanism(s) of activation, we attempted to reconstitute transcription from the Eiv promoter using purified components. It has been shown that transcription from the adenovirus major late promoter (AdMLP), containing the minimal promoter elements (the TATA box and cap site), required at least five general transcription factors (IIA, IIB, IIE, IIF, and IID), in addition to RNA polymerase II (Reinberg and Roeder 1987; Reinberg et al. 1987). Transcriptional template activity from the Eiv promoter was not observed when reaction mixtures containing these partially purified general transcription factors, RNA polymerase II, and DNA carrying the Eiv promoter were incubated under transcription conditions; whereas the Ad-MLP included in the same reaction was transcribed. However, when different amounts of nuclear extract (prepared from uninfected HeLa or Ad-5-infected HeLa cells) were added to the reaction mixture, the Eiv promoter became transcriptionally active (data not shown; see below). This functional complementation assay was used to isolate a factor necessary for Eiv transcription (EivF) from nuclear extracts.

The purification of EivF is summarized in Table 2 and described in Experimental procedures. The HeLa factor copurified during the first two steps of the procedure (phosphocellulose and DEAE-Sephacel) with the general transcription factor IIB. These two factors could be separated after gel filtration through a column of Sephacryl S-300 in the presence of high salt $(1.0 \mathrm{M} \mathrm{KCl})$. Transcriptionally active EivF eluted with an apparent molecular weight of $57,000-89,000$, whereas TFIIB activity eluted (Reinberg and Roeder 1987) with an apparent molecular weight of $29,000-32,000$, as reported previously (data not shown). When the column fractions were assayed for their ability to bind to the Eiv promoter on a gel retardation assay, binding activity specific for the Eiv recognition site [GT/G/T/ACGT] was present in a broad peak, including almost all the fractions of the column and producing DNA-protein complexes that had different electrophoretic mobilities (data not shown). To investigate this further, the binding activity was analyzed by DNase I footprinting experiments. Footprints to the 5'-GTGACGT-3' sequence in the distal EIa enhancer core sequence (between -170 and -163 ) and to the $5^{\prime}$ GTTACGTCA-3' sequence in the site proximal to the TATA box (between -58 and -47 ) were observed in almost all of the fractions analyzed (Fig. 2). Also, fractions numbered 162-168 yielded two additional weak footprints. One mapped to the sequence $5^{\prime}$-GTGACGA- 3 ' in the proximal EIa enhancer core sequence (between nucleotides -147 and -140 ), and the other was located between nucleotides -128 and -120 (for details, see 
Cortes et al.

Table 1. CAT activity in soluble extracts derived from cells transfected with DNAs carrying different Eiv promoter-deletion mutant-CAT constructs

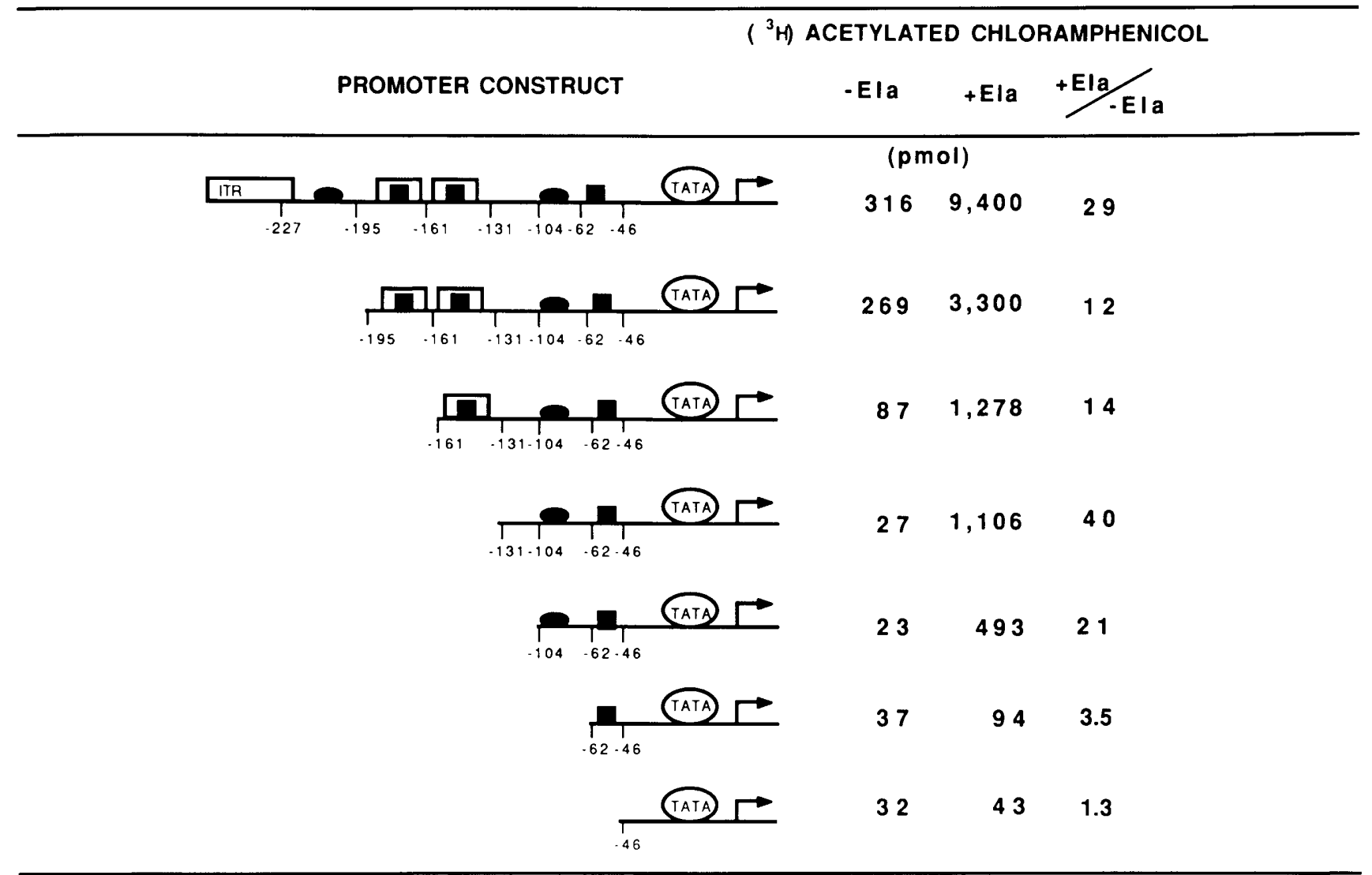

Transfection and CAT assays were carried out as described in Experimental procedures. The different Eiv promoter constructs (5 $\mu \mathrm{g})$ used in the transfection experiments are indicated in the table. Cells were also cotransfected with a plasmid DNA containing the EIa gene or pJAM $(5 \mu \mathrm{g})$ and a plasmid DNA containing the $\beta$-globin promoter $(5 \mu \mathrm{g})$. Extracts were diluted to the same protein concentration. To be certain that assays were carried out on a linear range, three different amounts of extracts were assayed. Values represent an average of four independent assays, using $60 \mu \mathrm{g}$ of extract. The efficiency of transfection was monitored by analyzing the amount of $\beta$-globin RNA produced as described previously (Costa et al. 1986).

Fig. 6). One interpretation of these results was that the footprinting activity to the $5^{\prime}-\mathrm{GT}(\mathrm{G} / \mathrm{T}) \mathrm{ACG}(\mathrm{T} / \mathrm{A})-3^{\prime}$ sequence present in the column fractions could be the result of different proteins interacting with this sequence,

Table 2. Purification of EivF

\begin{tabular}{lrrr}
\hline & & \multicolumn{2}{l}{ Total } \\
& mg protein & units & Units/mg protein \\
\hline Nuclear extract & 3500 & 310,000 & 88 \\
Phosphocellulose & 276 & 205,000 & 742 \\
DEAE-Sephacel & 196 & 197,000 & 1000 \\
Sephacryl S-300 & 25 & 102,000 & 4080 \\
DNA affinity & & 32,000 & \\
\hline
\end{tabular}

All steps were as described in Experimental procedures. One unit of EivF was defined as the amount of protein that catalyzed the incorporation of 1 pmole of nucleotide into a 1500-nucleotide transcript originated from the Eiv promoter in $45 \mathrm{~min}$ under the conditions specified in Experimental procedures. The amount of protein in the DNA affinity step is unknown. each having a different molecular weight.

Transcriptionally active fractions $(150-162)$ were pooled. To analyze further whether binding and transcriptional activities copurified, an aliquot of the pool was sedimented through a high salt $(1.0 \mathrm{M} \mathrm{KCl})$ glycerol gradient, and fractions were assayed for both transcriptional and DNA-binding activities. The transcriptional activity sedimented at $4.9 \mathrm{~S}$ in front of the BSA marker (Fig. 3). Two different peaks of DNA-binding activity were observed when the fractions were assayed for their ability to bind to the Eiv promoter. The slower sedimenting form was displaced slightly (by one fraction) from the transcriptional activity (Fig. 3). This may be due to interfering activities present in the fractions; such examples have been observed previously with other transcription factors (Dynan and Tjian 1983b; Reinberg and Roeder 1987). The faster sedimenting form has not yet been characterized.

Additional purification of EivF was accomplished by three passages of EivF through a DNA affinity column 

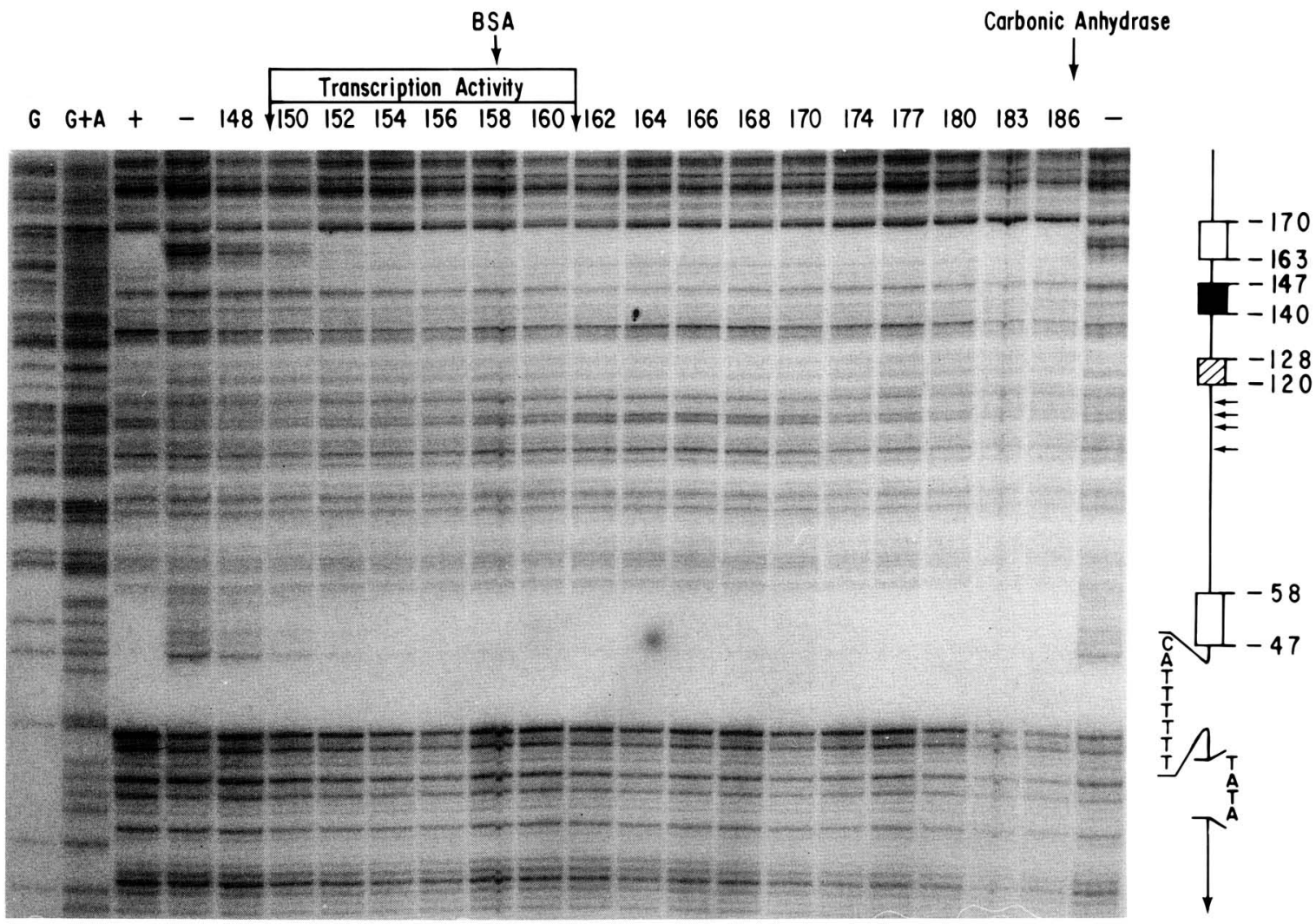

Figure 2. Fractionation of EivF on a Sephacryl S-300 column. The DEAE-Sephacel fraction (200 mg protein) derived from HeLa cell extracts was fractionated on a Sephacryl S-300 column $(1.4 \times 120 \mathrm{~cm})$. The column was equilibrated with buffer C containing $1.0 \mathrm{M}$ $\mathrm{KCl}$. The fractionation was performed at $9 \mathrm{ml} / \mathrm{hr}$. Fractions of $1.0 \mathrm{ml}$ were collected and dialyzed against buffer $\mathrm{C}$ containing $0.1 \mathrm{M}$ $\mathrm{KCl}$, and aliquots were assayed for DNA binding to the Eiv promoter, as well as in the Eiv-specific transcription assay. DNase I footprinting reactions were carried out as described in Experimental procedures. Each assay tube received a 10- $\mu \mathrm{l}$ aliquot of a fraction, as indicated at the top. The DNA fragment used $(2 \mathrm{ng})$ containing the Eiv promoter was 3 '-end labeled at the HindIII site located $71 \mathrm{bp}$ downstream from the cap site (coding strand). The control pattern of DNase I digestion obtained in the absence of protein is indicated with a negative symbol $(-\mid)$ at the top. The positive symbol $|+|$ represents the reaction that received EivF. The boxes at the side of the figure represent the relative positions of regions protected from DNase I digestion. The EivF transcriptional activity was determined by assaying an aliquot $(5 \mu \mathrm{l})$ of the different fractions in the Eiv-specific transcription assay. Reaction mixtures were as described in Experimental procedures and contained a plasmid DNA carrying the Ad-MLP $(0.2 \mu \mathrm{g})$ as an internal control and a plasmid DNA carrying the Eiv promoter from which the ITR sequences had been deleted. In addition, reaction mixtures were supplemented with partially purified transcription fators IIA (DEAE-cellulose fraction, $2.2 \mu \mathrm{g}$ ), IIB (Sephacryl S-300 fraction, $1.3 \mu \mathrm{g}$ ), IIE/IIF (Sephacryl S-300 fraction, $2.4 \mu \mathrm{g}$ ), IID (DEAE-cellulose fraction, $2.9 \mu \mathrm{g}$ ), Sp1 (DNA affinity fraction, $1 \mu$ l), and HeLa cell RNA polymerase II (35 $\mathrm{ng}, 175,000 \mathrm{units} / \mathrm{mg}$ protein). The amount of radiolabeled nucleotides incorporated into the Eiv transcript was determined by excising the corresponding bands and counting in a scintillation counter.

containing multiple copies of the GTGACGT heptanucleotide (see Experimental procedures). The specific DNA-binding activity associated with EivF (measured on a gel retardation assay) eluted in a $2.0 \mathrm{M} \mathrm{KCl}$ wash (data not shown). EivF recovered after the third passage over the DNA affinity column was transcriptionally active (see below) and bound to two regions of the Eiv promoter (Fig. 4A).

When fractions of the different steps of the purification were analyzed by polyacrylamide-SDS gel electrophoresis and the proteins visualized by silver staining, it was possible to observe that the above purification scheme resulted in the isolation of two proteins that migrated in the molecular weight range of 72,000 and 65,000 (Fig. 5A). To determine whether the 65,000dalton and/or 72,000-dalton protein corresponded to EivF, the purified protein(s) were separated on a preparative polyacrylamide-SDS gel. Slices of the gel containing denatured proteins were excised, as indicated on the left-hand side of Figure 5A, and the proteins eluted and renatured by the method of Hager and Burgess (1980). The proteins were assayed for their ability to bind to the Eiv promoter on a gel retardation assay (Fig. 5C). Bands $a$ and b (migrating as 72,000 and 65,000 
daltons, respectively, when separated for a second time on polyacrylamide-SDS gel, Fig. 5B/ were able to bind to the Eiv promoter (Fig. 5C, lanes 4 and 6 ) and yielded a DNA-protein complex that migrated to the same position as one of the complexes formed with the protein from the DNA affinity step (prior to isolation from the polyacrylamide-SDS gel). However, band $b$ appeared to produce a second complex that migrated faster (lane 6). The binding activity observed with bands $a$ and $b$ was specific for the EivF recognition site because it could be competed by oligonucleotides that contained the sequence 5'-GTGACGT-3' (lanes 5 and 7). The material eluted from band c (Fig. 5A) was not able to bind to the Eiv promoter (Fig. 5C, lanes 8 and 9). The slower migrating DNA-protein complex formed with the protein from the DNA affinity steps probably represents the binding of EivF to the two sites present in the Eiv promoter. The faster migrating form (lanes 2-4 and 6) probably represents the binding of EivF to only one site in the Eiv promoter.

The nature of these two polypeptides is unknown. It is possible that the 65,000 -dalton protein is a proteolized form of the 72,000-dalton protein; however, it is also possible that the differences in molecular weight represent different post-translational modifications. This is currently under study.

\section{Affinity-purified EivF is transcriptionally active}

The results described in the previous section indicated that affintiy-purified EivF could bind to the Eiv promoter (Fig. 4A). To ascertain whether the protein was also transcriptionally active, different amounts of affinity-purified EivF la mixture of the 65,000 and 72,000 daltons) were added to reaction mixtures containing the general transcription factors IIA, IIB, IIE/IIF, IID, RNA polymerase II, the Eiv promoter, and the MLP. In the absence of EivF, the MLP was transcriptionally active and low levels of transcription were observed from the Eiv promoter. There low levels of Eiv transcription were probably the result of the general transcription factors operating via the TATA sequence [Fig. 4B, left lane indicated by a negative symbol $(-1)$. However, the addition of purified EivF gave specificity to the reaction, as indicated by the suppression of nonspecific transcription observed in its absence (Fig. 4B, left lane), and led to the production of a specific Eiv transcript (Fig. 4B, lanes labeled $1 \times, 2 \times$, and $4 \times$; transcription from the MLP was not affected. Thus, affinity-purified EivF was specific for the Eiv promoter and was transcriptionally active.

The above results demonstrated that the mixture of the 65,000- and 72,000-dalton proteins was able to specifically drive transcription from the Eiv promoter. Because we have not been able to recover a transcription-

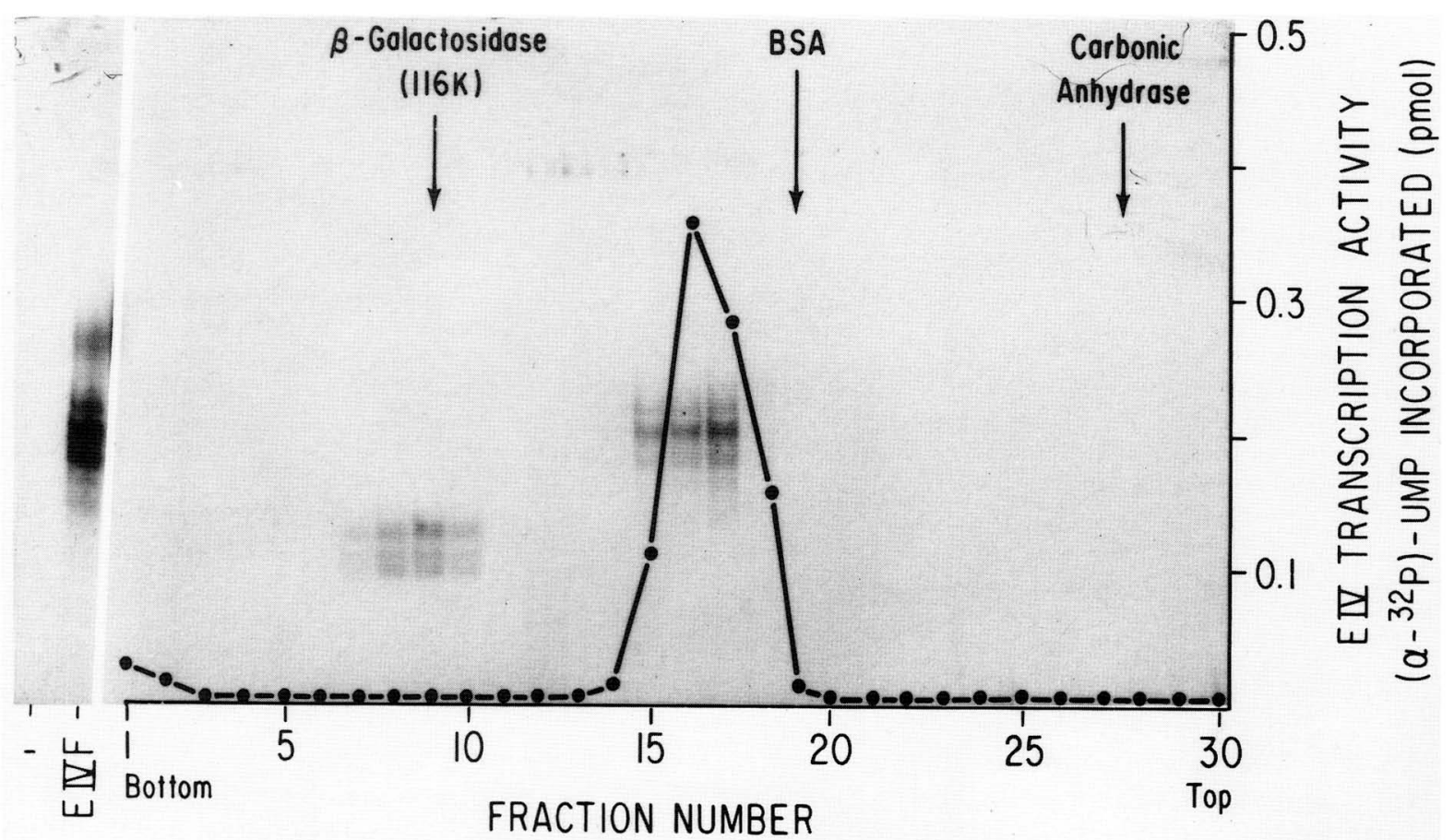

Figure 3. Cosedimentation through a glycerol gradient of the DNA-binding and transcription activities associated with EivF. A $300-\mu l$ aliquot of EivF from the Sephacryl S-300 pool was dialyzed against buffer C containing $10 \%$ glycerol and $1.0 \mathrm{M} \mathrm{KCl}$ and loaded onto a 5-ml, 15-35\% glycerol gradient formed in buffer C containing $1.0 \mathrm{M} \mathrm{KCl}$. Sedimentation was at $45,000 \mathrm{rpm}$ for $24 \mathrm{hr}$ at $4{ }^{\circ} \mathrm{C} \mathrm{in}$ an SW 55 rotor. Fractions of $\sim 160 \mu \mathrm{l}$ were collected from the bottom of the tube and dialyzed against buffer $\mathrm{C}$ containing $0.1 \mathrm{M} \mathrm{KCl}$. An aliquot $(5 \mu \mathrm{l})$ was removed from each fraction and assayed for transcription activity, as indicated in the legend to Figure 2 . Another aliquot $(5 \mu 1)$ was assayed for DNA-binding activity, as described in Experimental procedures. A 328-bp DNA fragment containing the Eiv promoter up to -228 was used. The transcription and DNA-binding activities are superimposed. 


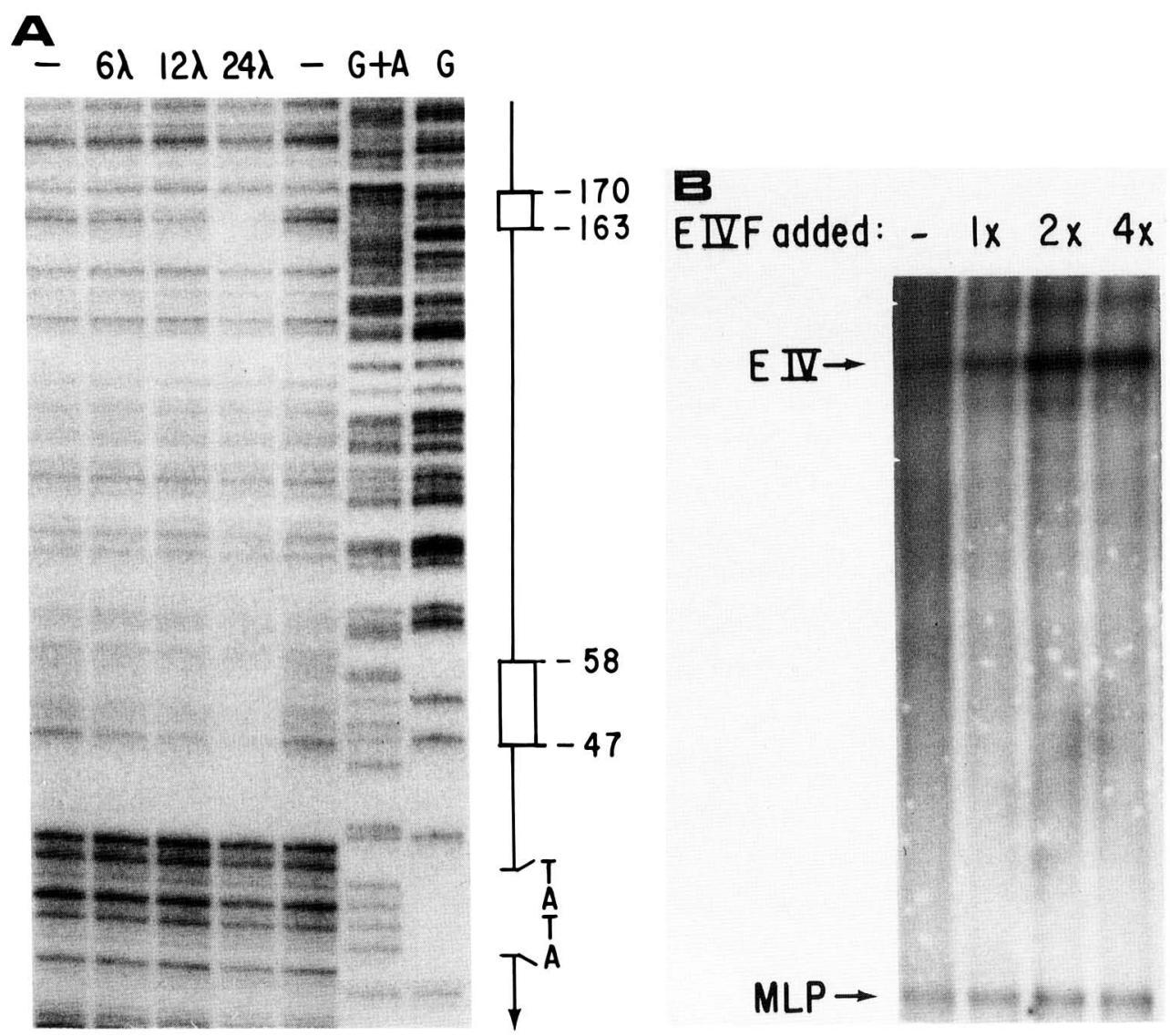

Figure 4. $(A)$ DNase I footprinting analysis of affinity-purified EivF on the Eiv promoter. The footprinting reaction was carried out as described in Experimental procedures and contained DNA $(\sim 2 \mathrm{ng}$ ) and affintiy-purified EivF (as indicated at the top). The control pattern of DNase I digestion obtained in the absence of EivF is indicated with a negative symbol $|-|$ at the top. The relative position of regions protected from DNase I digestion are indicated as open boxes (right). (B) Affinity-purified EivF is transcriptionally active. Reaction conditions were as described in Experimental procedures and contained transcription factors IIA [single-stranded (ss) DNA agarose fraction, $0.9 \mu \mathrm{g}$ ), IIB (ssDNA agarose fraction, $0.25 \mu \mathrm{g}$ ), IIE (Affi-gel blue fraction, $0.9 \mu \mathrm{g}$ ), IID (ssDNA agarose fraction, $0.3 \mu \mathrm{g}$ ), Spl (DNA affinity step, $1 \mu \mathrm{l}$ ), RNA polymerase II ( $35 \mathrm{ng}, 175,000 \mathrm{units} / \mathrm{mg}$ protein), and a plasmid DNA containing the Eiv promoter $(0.2 \mu \mathrm{g})$. In addition, transcription reactions were supplemented with different amounts of affinity-purified EivF, as indicated at the top. The amount of radiolabeled nucleotide incorporated into the specific transcripts was measured by excising the bands of the dry gel and counting in a scintillation counter. The numbers expressed in pmoles of [ $\left.{ }^{32} \mathrm{P}\right] \mathrm{UMP}$ incorporated into the Eiv and ML transcripts were no $\operatorname{EivF}(-), 0.15$ and $0.3 ; 1 \times \operatorname{EivF}, 0.35$ and $0.3 ; 2 \times \operatorname{EivF}, 1.2$ and $0.4 ; 4 \times$ EivF, 1.0 and 0.4 , respectively.

ally active form of the proteins after renaturation from the polyacrylamide-SDS gel, it is currently unknown whether either polypeptide can drive transcription independently. However, the ratio of the two proteins varied between preparations and appears to have no relation with transcription activity. Preparations containing approximately equal amounts of the 72,000- and 65,000dalton proteins (Fig. 5A) were as active as preparations that were enriched in the 65,000-dalton protein (Fig. 5B).

\section{Binding of EivF and EivF-related factors to the Eiv promoter}

The Eiv promoter contains three sites that should serve as recognition sequences for EivF (see Fig. 1A). Lee and Green (1987) demonstrated that nuclear extracts from
HeLa cells contained an activity that bound to two sites (sites A and B) within the Eiv promoter. However, their footprints to site A extended over both of the two EIa enhancer core sequences (from -178 to -138 ) at high concentrations of nuclear extract. A possible explanation, as suggested by these investigators, was the presence of two sites, each with different binding affinity. Another possibility raised was that a factor other than the transcriptionally active EivF was binding to the proximal Ela enhancer core sequence.

Footprinting studies with purified EivF indicated that only two sites in the promoter, one located upstream from the TATA box between nucleotides -57 and -46 and one located in the distal EIa enhancer core sequence between nucleotides -170 and -163 , were actually recognized (Fig. 4A). Footprinting to the 5'-GTGACGA-3' 

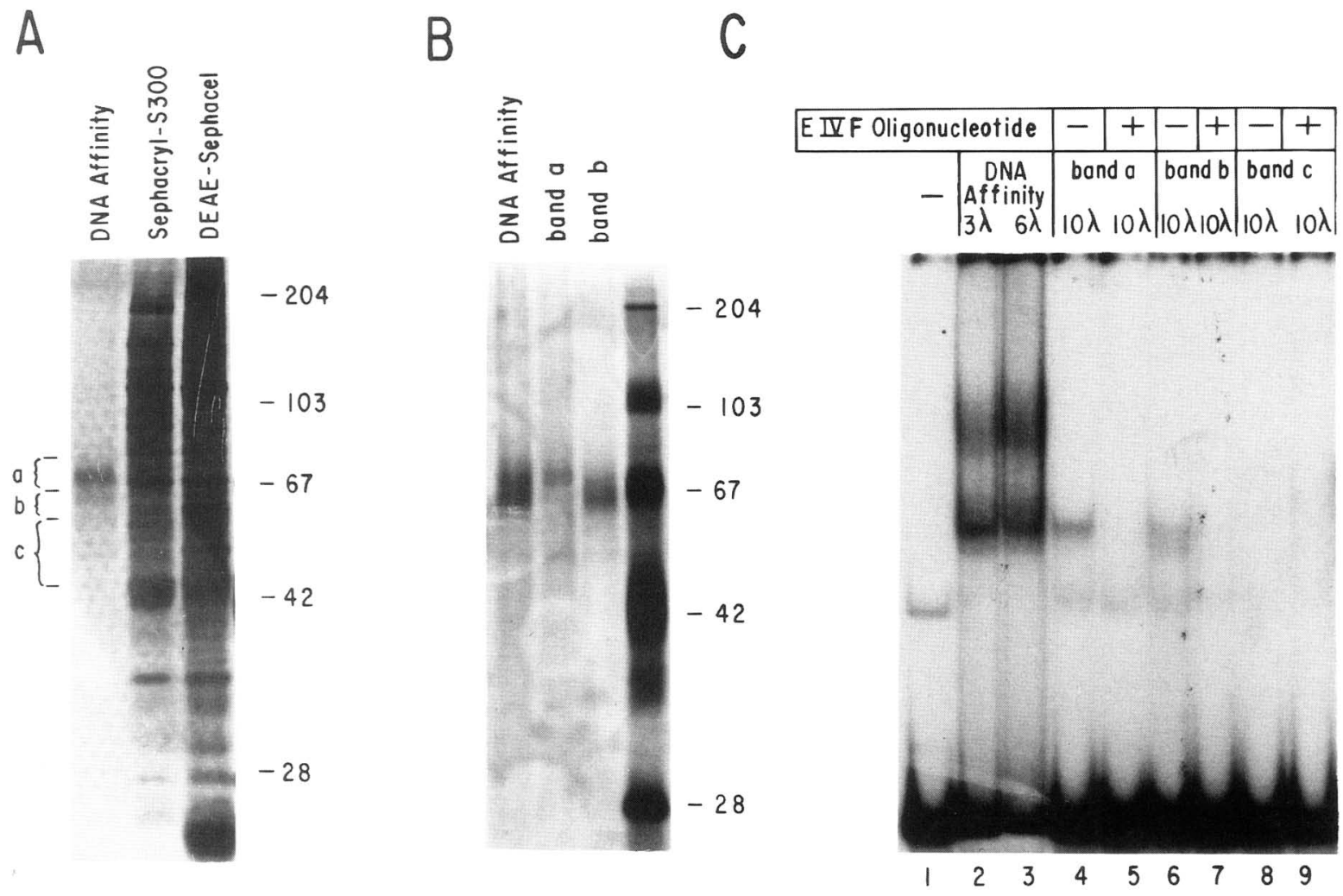

Figure 5. Analysis of the polypeptides containing EivF activity. (A) SDS-polyacrylamide gel electrophoresis of the different steps in the purification of EivF visualized by silver staining. The lanes display the polypeptides present in the different stages of purification, as indicated at the top, when equivalent amounts of EivF (160 units, transcription activity) were analyzed on a $10 \%$ gel. $(B)$ Analysis (by SDS-polyacrylamide gel electrophoresis) of the proteins eluted from an SDS-polyacrylamide gel. Protein bands labeled a, b, and c in the SDS-polyacrylamide gel in $A$ were cut and eluted as described in the text. A fraction of the renatured protein (10 $\mu l)$ was analyzed on a $10 \%$ SDS-polyacrylamide gel. Lanes represent the polypeptides present in the DNA affinity step and in the material eluted from bands $a$ and $b$, as indicated at the top. The lane on the right contained protein molecular weight markers. $(C)$ DNAbinding activity in the renatured proteins isolated from an SDS-polyacrylamide gel. Binding assays were as described in Experimental procedures and contained an aliquot (as indicated at the top) of proteins in the DNA affinity step or of the material isolated from bands a, b, or c. Reaction mixtures received a 3' end-labeled 328-bp DNA fragment (9 ng) containing the Eiv promoter and competitor DNA. Lanes $1-4,6$, and 8 received $0.4 \mu \mathrm{g}$ of plasmid DNA containing the Eiv promoter in which the elements upstreams of -46 were deleted. Lanes 5,7 , and 9 received $9.0 \mathrm{ng}$ of a double-stranded oligonucleotide that contained the EivF recognition site. The slow migrating band observed in lane 1 , representing a low percentage of the labeled DNA added, probably represents an anomalous migration of the probe, which is present occasionally. We do not yet understand its origin.

sequence located in the proximal Ela enhancer core sequence (between nucleotides -147 and -140 ) was not detected with transcriptionally active EivF. The inability of EivF to bind to the proximal EIa enhancer core sequence correlates well with the deletion experiments indicating that the removal of this element did not affect EIa-mediated activation of the Eiv promoter (Table 1). However, a fraction that eluted from a gel filtration column within a molecular weight range of 47,000 daltons (relative to protein standards) contained a factor(s) capable of binding to the sequence GTGACGA (Fig. 2). To analyze this further, variable amounts of three fractions of the Sephacryl S- 300 column, each representing a different molecular weight [fractions 153, 167 , and 186, named EivF, AP1, and CREB, respectively (see below)] were analyzed in a footprinting experiment. As expected, the transcriptionally active fraction 153,
EivF, bound to two different regions on the Eiv promoter, mapping to the distal EIa enhancer core sequence and to a site located upstream of the TATA box (Fig. 6, lanes 3-7). Fraction 167, AP1 ${ }^{\circ}$, gave protection at five different sites in the promoter (lanes 8-11). Two mapped to the same locations obtained with fraction 153; however, three additional footprints were observed. One mapped between position -147 and -140 and included the sequences $5^{\prime}$-GTGACGA-3', located in the proximal EIa enhancer core sequence (see Fig. 1A). Another site was observed between nucleotides -130 and -120 and included the sequence $5^{\prime}$-GTTGTGGG-3'. Interestingly, the sequence GTGGG also appears between the two EIa enhancer core sequences (nucleotides - 160 and -155 ). In this case, the footprint appeared as an extension of the protection observed in the distal EIa enhancer core sequence (see Fig. 6; lane 11). Fraction 186, 
CREB, transcriptionally inactive, yielded two footprints similar to those obtained with fraction 153 (lanes $12-15)$. The above results suggested that the binding activity to the proximal EIa enhancer core sequence was due to an activity different from EivF, which was present in fraction 167 .

To analyze further the specificity of binding present in fraction 167, competition experiments using oligonucleotides were performed. Previous studies have demonstrated that the sequence $5^{\prime}$-GTGACTCA-3', which is remarkably similar to the EivF core sequence $15^{\prime}$ GTGACGT-3'), was recognized by a 46,000 -dalton protein (Lee et al. 1987). This sequence, present in the SV40 enhancer and in the enhancer element of the human metallothionein IIa and human collagenase genes, has been shown to be recognized by purified transcription factor APl (Lee et al. 1987). Binding activity, in fraction 167 , to the proximal and distal EIa enhancer core sequences, as well as to the EivF site located proximal to the TATA box, was competed by oligonucleotides containing the EivF recognition site (Fig. 7A, cf. lane 3 with lanes 6 and 2). The addition of oligonucleotides containing the AP1 recognition site (lane 4), resulted in competition of the binding to the proximal EIa enhancer core sequence (cf. lane 4 with lanes 6 and 2) and to a partial competition of the binding to the distal EIa enhancer core sequence, as well as to the site proximal to the TATA box (cf. lane 4 with lanes 6 and 2). The addition of oligonucleotides containing the AP1 and EivF recognition sites (lane 5) resulted, as expected, in competition of the binding to the EIa enhancer core elements, as well as to the site proximal to the TATA sequence. However, the binding to the two GTGGG boxes located approximately at positions -125 and -157 was not affected (cf. lane 5 with lane 6). The binding to the GTGGG element was competed only by oligonucleotides containing the sequence 5'-GTGGG-3' (lane 6). The binding activity to the EivF recognition sites present in fractions 153 and 186 was competed by oligonucleotides containing the EivF recognition site (Fig. $7 \mathrm{~B}$, lanes 5 and 8 , respectively) but was not affected by oligonucleotides containing the AP1 recognition site (lanes 6 and 9). The extent of the area protected in the distal EIa enhancer core sequence cannot be determined accurately in this particular analysis; and the protection from -163 to -180 (indicated on the right-hand side of

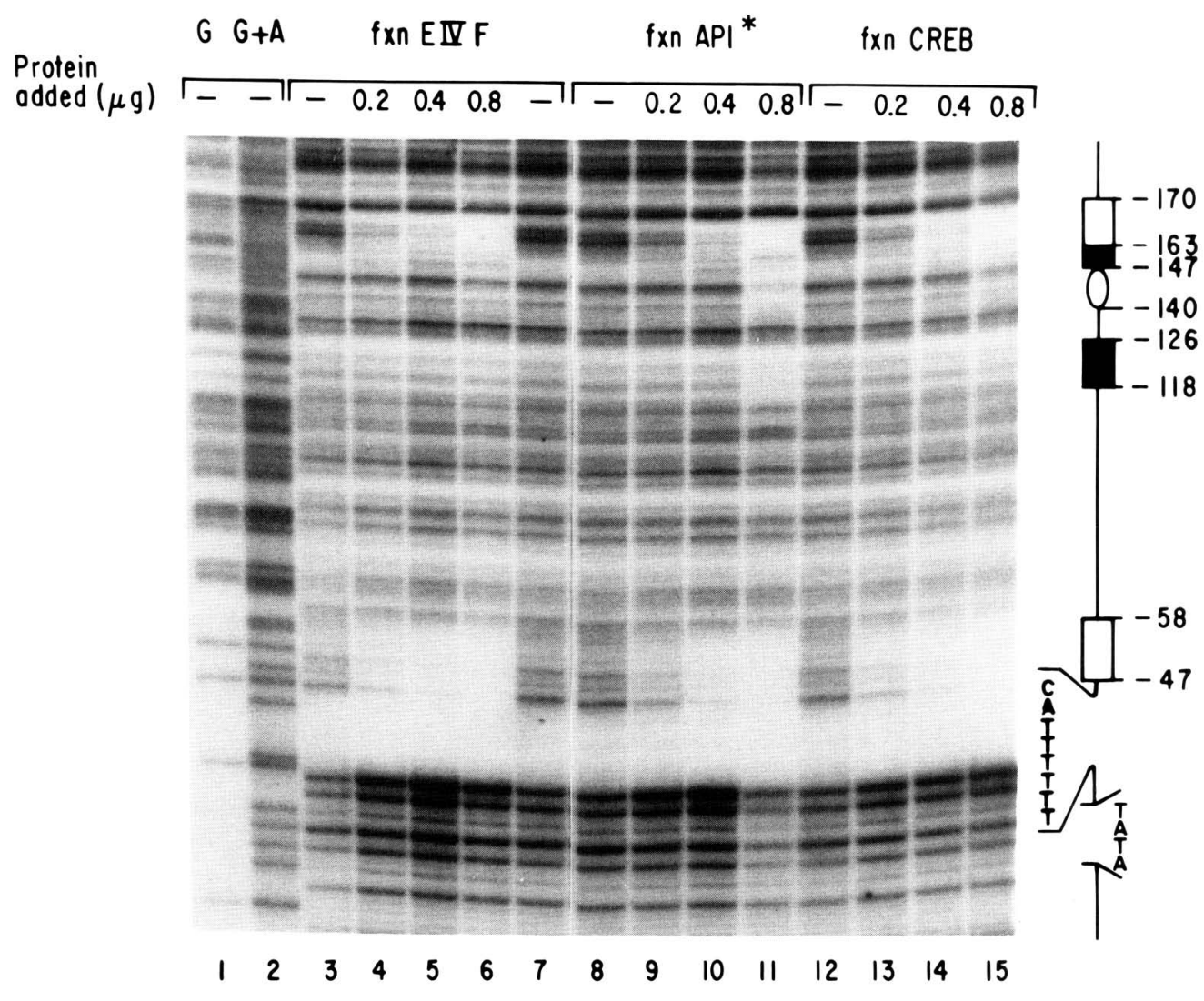

Figure 6. Analysis of the DNA-binding activities present in three fractions of the Sephacryl S-300 column. DNase I footprinting reactions were carried out as described in Experimental procedures and contained different amounts of protein from three fractions of the Sephacryl S-300 column, as indicated at the top. The DNA fragment used ( $2 \mathrm{ng}$ ) containing the Eiv promoter was 3' end labeled at the HindIII site located $71 \mathrm{bp}$ downstream from the cap site. The control pattern of DNase I digestion obtained in the absence of protein is indicated with a negative symbol $(-)$ at the top. The boxes (right) represent the relative positions of regions protected from DNase I digestion. 
Cortes et al.

A

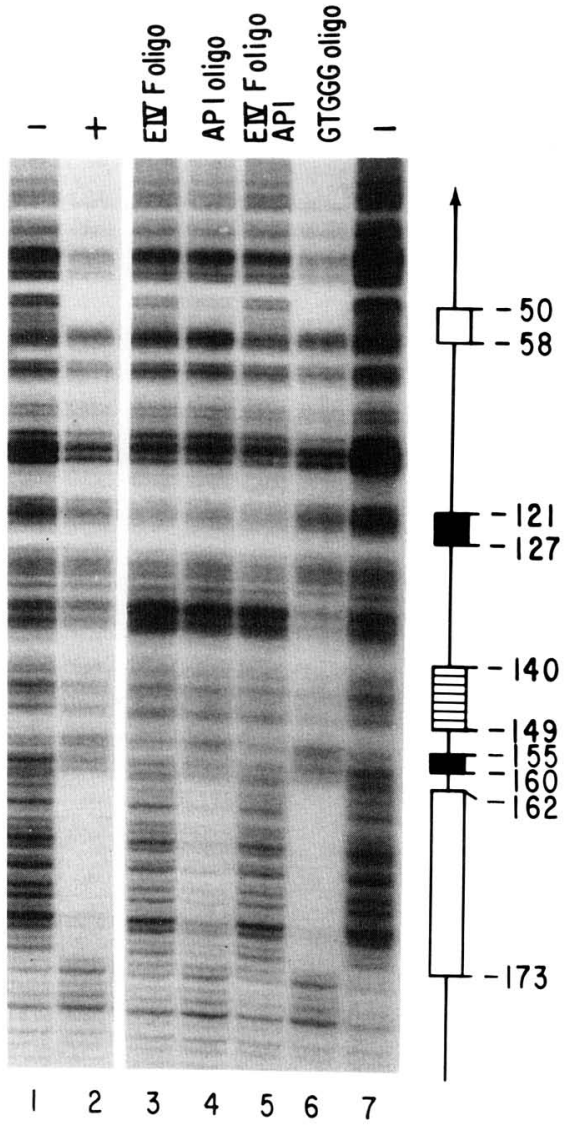

B

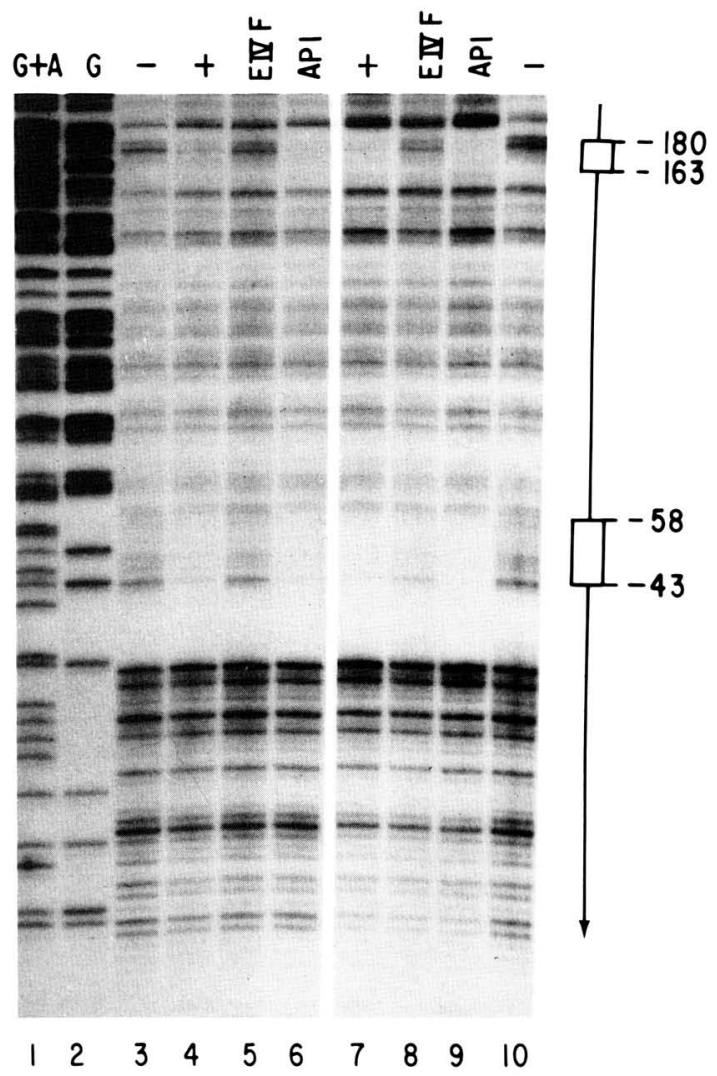

Figure 7. Competition of the DNA-binding activites present in three fractions of the Sephacryl S-300 column. DNase I footprinting reactions were carried out as described in Experimental procedures and contained protein $(0.8 \mu \mathrm{g})$ from the fraction APl $(A)$ or from the fractions EivF and CREB $(B$, lanes 3-6 and 7-10, respectively) The DNA fragment $(2 \mathrm{ng})$ contained the Eiv promoter and was labeled at the $E c o$ RI site located 359 nucleotides upstream from the cap site (noncoding strand in $A$ ) or at the HindIII site located 71 nucleotides downstream from the cap site (coding strand in $B$ ). The double-stranded oligonucleotides used as specific competitors (100 $\mathrm{ng}$ ) are indicated at the top. The control pattern of DNase I digestion obtained in the absence of protein is indicated with a negative symbol $|-|$ at the top. The control pattern of DNase I digestion obtained in the presence of protein but in the absence of the specific oligonucleotide is indicated by a positive symbol $|+|$ at the top. The boxes in the drawing at the right of $A$ and $B$ represent the relative positions of regions protected from DNase I digestion.

Fig. 7B) is approximate. The exact limits of the protected area are from -162 to -173 , as indicated on the righthand side of Figure 7A. Thus, it appears that the binding activity to the proximal EIa enhancer core sequence present in fraction 167 was AP1 or an APl-like factor and that this factor could bind to the EivF recognition site. Furthermore, the above experiments also demonstrated that the sequence $5^{\prime}$-GTGGG-3' present in the Eiv promoter (between the two EIa enhancer core sequences and also at position - 125) served as recognition for a factor different from EivF and AP1. Interestingly, this sequence is also present between the two EivF sites located in the ITR (P. Cortes and D. Reinberg, unpubl.). The role of this element in Eiv transcription is currently unknown; however, it is interesting to note that a deletion of the sequences in the Eiv promoter from - 131 to -103 , including the GTGGG element, resulted in a threefold decrease in Ela-mediated activation /see Table $1)$.

\section{Multiple factors can bind to the EivF recognition site}

As indicated previously, transcriptionally active EivF eluted from a gel filtration column developed with a buffer containing high salt with an apparent molecular weight of $57,000-89,000$. However, when the column fractions were assayed for their ability to bind to the Eiv promoter, binding activity was present in almost all of the fractions. To investigate further whether this result was due to the presence of different factors that can bind to the EivF recognition site and not to protein aggregation, aliquots of each fraction were removed and pooled, and the proteins separated according to molecular weight by electrophoresis on a preparative polyacrylamide-SDS gel. Slices of the gel containing denatured proteins of different molecular weight ranges were excised and the proteins eluted and renatured as indicated previously. The proteins were then assayed for their ability to bind to the Eiv promoter. Different pools of 
proteins could bind to the Eiv promoter, generating different DNA-protein complexes (Fig. 8A). Two DNAprotein complexes were formed with protein migrating in the large molecular weight range. One complex was formed with protein(s) eluting between 76,000 and 70,000 (lane 4), and another complex with protein(s) migrating between 70,000 and 64,000 (lane 5 ). The protein present in these complexes probably represents the two species that we have purified using a functional transcription assay. Other DNA-protein complexes were formed with proteins migrating in the molecular weight range of $48,000-31,000$ (lanes $9,10,13-17$ ). To analyze the sequence specificity of the protein(s) in these complexes, DNase I footprinting was performed (Fig. 8B). The protein(s) present in the different complexes bound to the same sequence, the EivF recognition site. Some of the proteins appeared to bind only to the site proximal to the TATA box; however, this is probably due to low recovery of activity from the polyacrylamide-SDS gel and a higher affinity of the factor(s) for the site located proximal to the TATA box (Lee and Green 1987).

The nature of these smaller molecular weight proteins (compared to transcriptionally active EivF) is unknown. It is possible that they are proteolyzed forms of EivF or that they represent a totally different protein that exhibits the same sequence specificity. The nature of the observed differences in migration of the DNA-protein complexes formed with the small molecular weight proteins is also unknown. It is possible that they represent different forms of proteolysis; on the other hand, it is also possible that they are post-translationally modified forms of EivF. It is interesting to note the periodicity in change of migration of each of the complexes formed with the small molecular weight protein(s), as if each of the complexes represents a constant change in the net

Figure 8. Proteins with different electrophoretic mobilities on polyacrylamide-SDS gels can bind to the GTGACGT sequence present in the Eiv promoter. A protein mixture $(300 \mu \mathrm{g})$ derived from pooling aliquots of each fraction of the Sephacryl S-300 column was precipitated with $10 \%$ trichloroacetic acid, resuspended in loading buffer, heated at $90^{\circ} \mathrm{C}$ for $15 \mathrm{~min}$, and the proteins separated, along with size markers, by electrophoresis on a slab polyacrylamide-SDS gel. An equal volume was loaded onto 10 adjacent lanes, and the two flanking lanes received half the volume. After electrophoresis, the two flanking lanes, containing the size markers and a representative aliquot of the protein mixture, were excised and the proteins visualized by Coomassie blue staining. The stained gels were aligned with the unstained gel, and pieces spanning different molecular weight size ranges, as indicated at the top of $A$ and $B$, were generated. The proteins from each slice were eluted, renatured as described previously (Hager and Burgess 1980), and assayed in a specific DNA-binding assay $(A)$. The DNA-binding assay was as described in Experimental procedures and contained a $3^{\prime}$ end-labeled DNA fragment that íncluded the Eiv promoter (up to -224$)$ and an aliquot $(10 \mu l)$ derived from the different gel slices, as indicated at the top of $A$ and $B$. The specificity of the DNA-binding activity was analyzed by DNase I footprinting (panel B), as described in Experimental procedures. A 25- $\mu \mathrm{l}$ aliquot of the renatured protein was used in this analysis. charge. Whatever the molecular bases for these changes are remains to be investigated.

\section{Eiv $F$ binds to the somatostatin and gonadotropin cAMP-responsive elements}

Cellular genes from which the levels of expression appear to be regulated by cAMP [somatostatin (Montminy et al. 1986), human chorionic $\alpha$-gonadotropin (Deutsch et al. 1987), phosphoenolpyruvate carboxykinase (Short et al. 1986), and others], have an element [ćAMP responsive element (CRE) (Montminy and Bilezikjian 1987)] that contains the sequence $5^{\prime}$-TGACGTCA-3'. This sequence is similar to the EivF and APl recognition sites. Furthermore, previous studies have reported the isolation of a 43,000-dalton phosphoprotein that bound to the CRE element (Montminy and Bilezikjian 1987). Thus, we investigated whether cAMP-regulated genes could

\section{A}

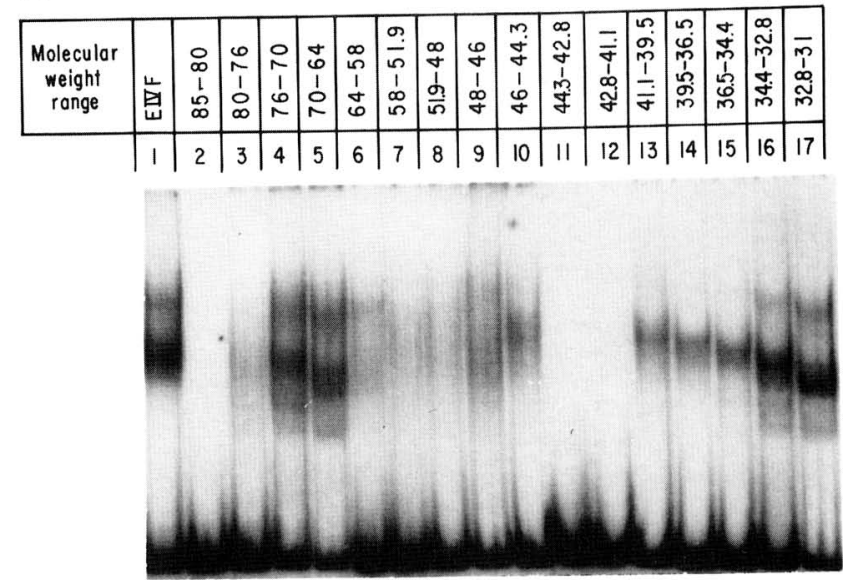

B

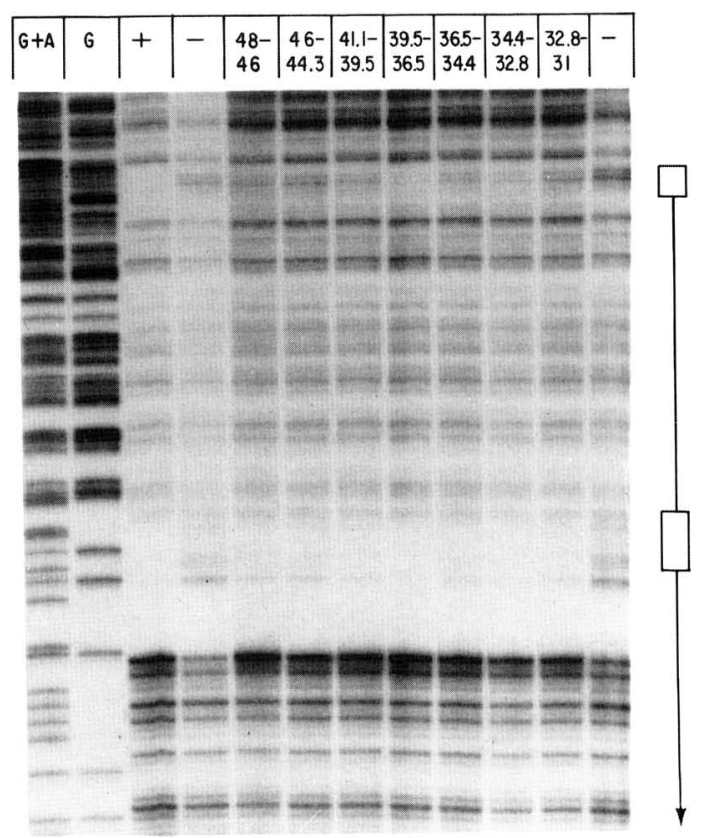


bind EivF. The addition of transcriptionally active EivF to a binding assay that contained the somatostatin or gonadotropin elements resulted in the formation of DNA-protein complex(s) that migrated slower than the unbound fragment (Fig. 9, lanes 2 and 3 and 8 and 9, respectively|. The binding was specific for EivF because it could be competed by the Eiv promoter or by the GTGACGT oligonucleotide (lanes 4 and 5 and 10 and 11), but not by an oligonucleotide that contained the APl recognition site (lanes 6 and 12). The ability of EivF to bind CAMP-responsive elements in vitro does not

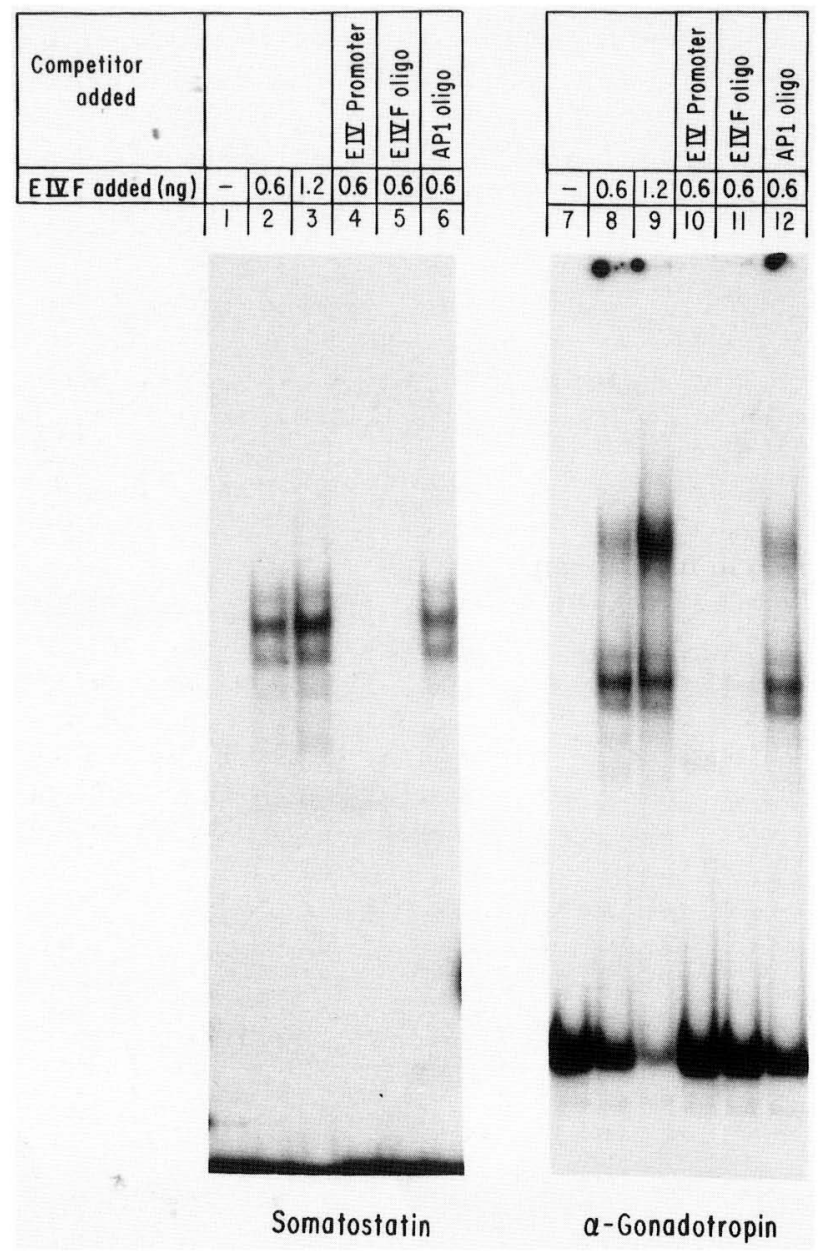

Figure 9. Binding of EivF to the somatostatin and gonadotropin promoters. The DNA-binding assays were as described and contained the somatostatin promoter in a 155-bp DNA fragment (left) or the human gonadotropin promoter in a 307-bp DNA fragment (right). The somatostatin fragments were generated by double digestion with EcoRI and PstI of plasmid $-100 \mathrm{r}$ (sms), containing one copy of the somatostatin CRE (rat somatostatin -56 to -33 ) ligated to the human $\alpha$-gonadotropin promoter $(-1$ to -100$)$ (P. Deutsch et al., unpubl.). The 307-bp DNA fragment containing the gonadotropin CRE was generated by digestion with BgIII and HindIII of plasmid DNA and $\mathrm{pA} 10+36 \mathrm{CAT}(\mathrm{r})$, which contains two tandem copies of the CRE (Deutsch et al. 1987). Variable amounts of EivF (Sephacryl S-300 fraction) and different competitors (20-fold molar excess) were added, as indicated at the top. prove that EivF itself mediates the activation of gene transcription by cAMP in vivo. It is possible that the 43,000-dalton protein isolated by Montminy and Bilezikiian (1987) is a proteolized form of EivF. On the other hand, it is also possible that different proteins can recognize the same core sequence but induce activation of different promoters.

\section{Discussion}

EivF, a factor required for transcription from the Eiv promoter, has been purified from extracts of HeLa cells. The factor directed transcription by binding to two elements located upstream of the Eiv cap site. One site was located within the distal EIa enhancer core sequence between nucleotides -170 and -163 . The other mapped near the TATA box between nucleotides -58 and -47 . EivF has an apparent molecular weight of 72,000 65,000 , as determined by gel filtration, glycerol gradient sedimentation, and renaturation of activity from a polyacrylamide-SDS gel.

\section{Eiv promoter}

The initial studies of Gilardi and Perricaudet demonstrated that the Eiv promoter was activated by the large polypeptide encoded by the EIa gene (Gilardi and Perricaudet 1984). Our studies, as well as those of others (Lee and Green 1987), confirm these results. The Ela-mediated stimulation of the Eiv promoter appears to involve EivF; removal of the distal EIa enhancer core sequence affected EIa- activation (Table 1). This is also supported by the observation that the two EivF-binding sites located in the ITR sequences (contained in a 49-bp fragment), were able to restore Ela-mediated activation of a promoter that contained a deletion of all the elements upstream of the TATA box (P. Cortes and D. Reinberg, unpubl.). These studies are in agreement with the results of Lee and Green (1987), which indicated that two copies of a 27-bp oligonucleotide containing the EivF recognition site (extending from -37 to -63 of the Eiv promoter/ were able to stimulate transcription of a deleted Eiv promoter when inserted at position - 138 /a construct in which the two EIa enhancer core sequences had been deleted; see Fig. 1).

The deletion studies described here suggest that the Eiv promoter contains elements downstream of -130 , other than the EivF recognition site, that participated in EIa-activation, as well as the maintenance of basal levels of transcription (i.e., in the absence of Ela and in vitro). One EivF-binding site, together with one Spl recognition site and the TATA box, were the minimum elements required for activation (Table 1). Lee and Green (1987) suggested that EivF was the only sequence-specific DNA-binding protein, other than the TATA binding factor, required for full Eiv promoter activity. Because their replacement experiments were performed on the Eiv promoter at position - 138 (containing a deletion of the two Ela enhancer core sequences but maintaining a GT-rich region and one Sp1-binding site; see 
Fig. 1) and we demonstrated that the deletion of sequences between -131 and -104 (containing a $5^{\prime}$ GTGGG-3' box), as well as the deletion of the Sp1binding site located at position - 100, affected Ela-mediated activation (Table 1), we suggest that other sequence-specific factors participated in transcription of the Eiv promoter. The identity of a factor that binds to the sequence $5^{\prime}$-GTGGG-3' was confirmed by footprinting competition experiments; binding to the GTGGG box was only competed by oligonucleotides containing the sequence 5'-GTGGG-3' (Fig. 7). This sequence also appears between the two EIa enhancer core elements and between the two EivF sites present in the ITR (P. Cortes and D. Reinberg, unpubl.). Thus, it seems that the EivF recognition site is clustered with sites that serve as recognition for other DNA-specific transcription factors (GTGGG-binding factor and Sp1). Two Splbinding sites are also located between the two EivFbinding sites in the ITR (P. Cortes and D. Reinberg, unpubl.). Our studes suggest that Ela-mediated activation of the Eiv promoter occurs via EivF; however, other sequence-specific transcription factors are also required. The role of $\mathrm{Sp} 1$ or the GTGGG box binding-protein in EIa activation is unknown; however, they may cooperate with EivF and/or the TATA-binding protein to encourage stable and productive binding of these factors to their cognate sites. A phenomenon like the one proposed here was observed with the glucocorticoid receptorbinding site and the $5^{\prime}$-CACCC-3' box-binding factor (Schule et al. 1988) and also between the Ad-MLP upstream factor and the TATA-binding protein (Sawadogo and Roeder 1985).

\section{EivF and EivF-related factors}

Different molecular weight proteins were detected that can bind to the sequence 5 - $-\mathrm{GT}$ (T/G)ACGT-3', the EivF recognition site (Figs. 2 and 8). Using a functional transcription assay, we purified to near homogeneity two proteins in the molecular weight range of 72,00065,000 , required for transcription from the Eiv promoter. Each protein was able to bind independently to the EivF recognition site. However, we were unable to determine whether each polypeptide $(72,000$ or 65,000 dalton) can direct transcription independently from the Eiv promoter. It is possible that the 65,000 -dalton protein is a proteolized form of the 72,000 -dalton protein or that it represents post-translational modification.

Genes whose expressions are controlled by the intracellular concentration of cAMP contain a CRE. The DNA sequence of this element is the same as that of the EivF recognition site. Montminy and Bilezikjian (1987) have isolated a 43,000-dalton phosphoprotein (CREB), from PC12 cells, that binds to the CRE. We have detected multiple polypeptides, ranging from molecular weights of $76,000-30,000$, present in HeLa cell extracts, that can recognize the EivF/CRE sequence (Fig. 8). However, the transcription activity specific for the Eiv promoter eluted from high salt gel filtration columns with a relative mass of $89,000-57,000$ daltons (Fig. 2) and sedimented through a high salt glycerol gradient with a value of $4.9 \mathrm{~S}$ (Fig. 3). The fact that the fractionation steps were performed in the presence of high salt $(1.0 \mathrm{M}$ $\mathrm{KCl}$ ) argue electrophoretic analysis of the DNA affinity column step reveals the presence of two polypeptides in the molecular weight range of 72,000-65,000 (Fig. 5A). Thus, our results strongly suggest that it is unlikely that the 43,000-dalton polypeptide is involved in Eiv transcription; however, we cannot rule out the possibility that EivF is responsible for maintaining basal levels of transcription, and another factor, perhaps a 43,000dalton protein, is responsible in the EIa induction of the Eiv promoter. Interestingly, Hurst and Jones (1988) have isolated a 43,000-dalton protein from uninfected HeLa cells that bound to the sequence $5^{\prime}$-GTGACGA-3' in the adenovirus early promoter III, as well as to the EivF recognition site. Our studies indicated that the sequence 5'-GTGACGA-3' was present in the proximal Ela enhancer core element. This element did not serve as a recognition for EivF (measured in a footprinting assay) nor did it participate in Ela activation, although it did participate in the maintenance of basal levels of transcription (Table 2; Fig. 1B) and served as recognition site for APl (Lee et al. 1987) or an AP1-like factor (Fig. 7). It is possible that the 43,000 -dalton protein isolated by Hurst and Jones is equivalent to the APl-like activity that we detected in the fractions of the gel filtration column (Figs. 3 and 9). The functional relationship between the 43,000-dalton protein, CREB, and EivF remains to be analyzed in more detail.

Our results suggest that DNA-binding assays alone, without functional transcriptional assays, are at best an uncertain means of isolating factors that may be involved in gene transcription. It is possible that the protein isolated by Montminy and Bilezikjian (1987) or by Hurst and Jones (1988) is a proteolyzed form of EivF. On the other hand, it is also possible that different proteins can recognize the same core sequences but induce activation of different promoters. Evidence supporting this idea has been obtained as indicated by the findings that multiple factors can bind to the CCAAT box (Dorn et al. 1987) or to the octanucleotide motif (Rosales et al. 1987; Xiao et al. 1987), present in the immunoglobulin enhancer and other promoters. Thus, the development of functional assays, reconstituted with purified proteins in which the interaction of the different components of the transcription machinery can be analyzed at the molecular level, will help to elucidate the mechanism(s) by which different promoters are activated.

\section{Experimental procedures}

\section{Plasmid DNA molecules and oligonucleotides}

The construction of plasmid DNAs containing the Eiv promoter and the different deletions of the Eiv promoter have been described (Leza and Hearing, in press). The oligonucleotides used were as follows: APl: 5'-GATCCTGACTCACGGG-3' and its complement $5^{\prime}$-GATCCCCGTGAGTCAG-3', Sp1: 5'GATCGGGGCGGGGC-3' and its complement 5'GATCGCCCCGCCCC-3', E2F: 5'-TCGACTTTTCGCGCGG$3^{\prime}$ and its complement 5'-GATCCCGCGCGAAAAG-3', 
MLTF: 5'-GATCCAGGTGTAGGCCACGTGACCGGGTG-3', and its complement 5 '-GATCCACCCGGTCACGTGGCCTACACCTG-3'

\section{In vitro transcription reactions}

Transcription reaction mixtures were as described previously (Reinberg and Roeder 1987); however, $2 \%$ polyethylene glycol (vol/vol) was added to the mixtures. The template DNA molecules used were plasmid DNA pD139 containing the Ad-MLP linearized with the restriction endonuclease BamHI. Transcription initiated from the cap site at the MLP generated an RNA molecule of 521 nucleotides. Plasmid DNAs containing the Eiv promoter were $\mathrm{pE} 4-227 /-46$ and $\mathrm{pE} 4-330 /-228$ and were linearized with the restriction endonuclease $H p a I$. Transcription from the Eiv cap site to the HpaI site generated an RNA molecule of 1500 nucleotides.

\section{Purification of the transcription factors}

General transcription factors IIA, IIB, IIE/IIF, IID, and HeLa RNA polymerase II were purified as described previously (Reinberg and Roeder 1987; Reinberg et al. 1987). Transcription factor Spl was purified by DNA affinity chromatography according to (Briggs et al. 1986).

\section{Purification of EivF}

EivF was purified from HeLa cells $\left(1.3 \times 10^{10}\right.$ cells $)$. Nuclear extract preparation (Dignam et al. 1983) and fractionation of the extract by phosphocellulose column chromatography was as described previously (Reinberg and Roeder 1987). The $0.5 \mathrm{M} \mathrm{KCl}$ phosphocellulose fraction ( $276 \mathrm{mg}$ protein) was purified further by chromatography on a DEAE-Sephacel column $110 \mathrm{mg}$ protein $/ \mathrm{ml}$ resin). The column was equilibrated with buffer $\mathrm{C}$ [20 $\mathrm{mm}$ Tris- $\mathrm{HCl}, \mathrm{pH} 7.9\left(4^{\circ} \mathrm{C}\right), 20 \%$ (vol/vol) glycerol, $0.2 \mathrm{mM}$ EDTA, $10 \mathrm{mM} \beta$-mercaptoethanol, $0.3 \mathrm{~mm}$ phenylmethylsulphonyl fluoride (PMSF)] containing $0.1 \mathrm{M} \mathrm{KCl}$. After loading (at a flow rate of three column volumes per hour\}, the column was washed with three column volumes of buffer $C$ containing 0.1 $\mathrm{M} \mathrm{KCl}$ and eluted with five column volumes of buffer $\mathrm{C}$ containing $0.35 \mathrm{M} \mathrm{KCl}$. EivF activity was found in the flow-through fractions. Fractions were pooled (196 mg protein) and the protein precipitated by the addition of solid ammonium sulfate $(0.33 \mathrm{~g} / \mathrm{ml})$ over the course of $30 \mathrm{~min}$ with constant agitation. The samples were stirred for an additional $30 \mathrm{~min}$, and the precipitated material was collected by centrifugation at $3.5 \times 10^{3}$ $\mathrm{rpm}$ for $60 \mathrm{~min}$ in a Ti-45 rotor. The pellet was resuspended to a total volume of $5 \mathrm{ml}$ with buffer $\mathrm{C}$ containing $1.0 \mathrm{M} \mathrm{KCl}$ and $0.01 \%$ Nonidet P-40 and loaded onto a 420-ml Sephacryl S-300 column $(1.4 \times 120 \mathrm{~cm})$ equilibrated with buffer $\mathrm{C}$ containing $1.0 \mathrm{M} \mathrm{KCl}$ and $0.01 \%$ Nonidet P-40. The column was developed at a flow rate of $9 \mathrm{ml} / \mathrm{hr}$, and fractions of $1 \mathrm{ml}$ were collected. Aliquots of $0.5 \mathrm{ml}$ were withdrawn from every other fraction and dialyzed for $60 \mathrm{~min}$ against 8 liters of buffer $\mathrm{C}$ containing $0.1 \mathrm{M} \mathrm{KCl}$. Aliquots $(5 \mu \mathrm{l})$ of the dialyzed material were then assayed for EivF activity.

Transcriptionally active EivF eluted from the high salt gel filtration column between 89,000 and 57,000 (relative to standard molecular weight markers). The transcriptionally active fractions were pooled $(0.7 \mathrm{mg} / \mathrm{ml})$, dialyzed against 4 liters of buffer $\mathrm{C}$ containing $0.1 \mathrm{M} \mathrm{KCl}$ and frozen at $-80^{\circ} \mathrm{C}$. Further purification of EivF was attained using a column containing multiple copies of the EivF DNA-binding site. A fraction of the
Sephacryl S-300 pool (3.5 mg of protein) was mixed with nonspecific competitor DNAs $(100 \mu \mathrm{g} / \mathrm{ml}$ poly[d(I-C) $) ; 100 \mu \mathrm{g} / \mathrm{ml}$ poly(dA) and poly (dT); $100 \mu \mathrm{g} / \mathrm{ml}$ poly and a plasmid DNA containing the Eiv promoter /with a deletion of all the elements upstream to $-46, \mathrm{pE} 4-330 /-46$; Leza and Hearing, in press $(15 \mu \mathrm{g} / \mathrm{ml})$, polyethylene glycol [to $2 \%$ (vol/vol) final concentration], and the mixture loaded onto a $3-\mathrm{ml}$ column equilibrated with buffer $Z$ [20 mM HEPES (pH 7.9), 20\% (vol/vol) glycerol, $0.2 \mathrm{mM}$ EDTA, $10 \mathrm{mM} \beta$-mercaptoethanol, $0.2 \mathrm{mM}$ PMSF] containing $0.1 \mathrm{M} \mathrm{KCl}$. The protein mixture and the resin were mixed in the column $(5-\mathrm{ml}$ syringe) and incubated (with occasional stirring) at $20-25^{\circ} \mathrm{C}$ for $30 \mathrm{~min}$. The column was washed (at a flow rate of two column volumes per hour) with five column volumes of buffer $\mathrm{Z}$ containing $0.4 \mathrm{M} \mathrm{KCl}$, followed by successive washes (three column volumes each) with buffer $\mathrm{Z}$ containing $0.5 \mathrm{M} \mathrm{KCl}$ and $2.0 \mathrm{M} \mathrm{KCl}$. Fractions of $0.5 \mathrm{ml}$ were collected, dialyzed against buffer $\mathrm{C}$ containing $0.1 \mathrm{M} \mathrm{KCl}$, and assayed for DNA-binding activity specific for the Eiv promoter. The active fractions were pooled and purified further by two additional cycles of DNA affinity column chromatography. The conditions for DNA binding were as described, however, the concentration of the competitor DNA was reduced to one half and one quarter of the original concentration for the second and third cycle, respectively.

\section{Preparation of DNA affinity column}

The oligonucleotide 5'-pGATCCGTGACGTGATCGATGTGACGTAG-3' and its complement 5'-pGATCCTACGTCACATCGATCACGTCACG-3' were hybridized and ligated with T4 DNA ligase. Oligomeric DNA was purified by chromatography on a Sephadex G-20 column (formed in a 10-ml plastic pipette). The excluded material was used to prepare the DNA affinity column. Columns were prepared as described by $\mathrm{Ka}$ donaga and Tjian (1986) or Kasner et al. (1986). The amount of polynucleotide bound to the column was $10 \mu \mathrm{g}$ of $\mathrm{DNA} / \mathrm{ml}$ resin. A ratio of $0.7 \mathrm{mg}$ protein $/ \mathrm{ml}$ of resin containing $10 \mu \mathrm{g}$ of DNA was used during the purification of EivF.

\section{DNA-binding assays}

DNA-binding assays were carried out in $25 \mu$ land contained 20 mM HEPES- $\mathrm{NaOH}$ buffer (pH 7.9), 60-150 mM KCl, $10 \%$ (vol/ vol) glycerol, $0.2 \mathrm{mM}$ EDTA, $2 \%$ (vol/vol) polyethylene glycol, nonspecific competitor DNAs $(100 \mu \mathrm{g} / \mathrm{ml}$ poly[d(I-C)]; 100 $\mu \mathrm{g} / \mathrm{ml}$ poly $(\mathrm{dA})$ and poly $(\mathrm{dT})])$ and a plasmid DNA containing the Eiv promoter ( with a deletion of all the elements upstream to $-45,15 \mu \mathrm{g} / \mathrm{ml}\}, \alpha^{-32} \mathrm{P}$ end-labeled DNA fragment containing the Eiv promoter (2-9 ng), and variable amounts of protein fractions, as indicated in the figures. Reaction mixtures were incubated at $30^{\circ} \mathrm{C}$ for $30 \mathrm{~min}$ and the DNA-protein complexes separated on $4 \%$ polyacrylamide gel.

\section{DNase I protection experiments}

Binding of EivF to a $3^{\prime}$ end-labeled DNA fragment containing the Eiv promoter was performed as described in the previous section. After incubation at $30^{\circ} \mathrm{C}$ for $30 \mathrm{~min}$, the reaction mixtures received $3 \mu \mathrm{l}$ of a solution containing $0.1 \mathrm{M} \mathrm{MgCl}_{2}, 5 \mathrm{mM}$ $\mathrm{CaCl}$, and $1 \mu \mathrm{l}$ of DNase I (Boehringer-Mannheim) that was freshly diluted to $10 \mu \mathrm{g} / \mathrm{ml}$. The mixtures were incubated for an additional $2 \mathrm{~min}$ at $25^{\circ} \mathrm{C}$. Maxam and Gilbert $\mathrm{G}$ and $\mathrm{G}+\mathrm{A}$ sequence ladders of DNA probes were prepared as described and subjected to electrophoresis on urea sequencing gels adjacent to the footprint reactions. 


\section{Cell culture}

HeLa cells used for the preparation of nuclear extracts and subsequent purification of the transcription factors were harvested in logarithmic growth $\left(7 \times 10^{5}\right.$ to $\left.9 \times 10^{5} \mathrm{cell} / \mathrm{ml}\right)$ from suspension culture in Joklick's modified medium (Hazleton) containing $5 \%$ calf serum. HeLa cells (clone 2 or S3) used in DNA transfection experiments were grown in tissue culture dishes with Dulbecco's modified Eagle's medium [DMEM (GIBCO)] supplemented with $10 \%$ fetal calf serum (FCS).

\section{DNA transfection and transient expression assays}

HeLa cells were cultured in DMEM supplemented with $10 \%$ heat-inactivated FCS. Transfection of DNA into cells was by the calcium phosphate coprecipitation method (Wigler et al. 1977), using $15 \mu \mathrm{g}$ of total DNA (5 $\mu \mathrm{g}$ plasmid DNA containing the Eiv promoter, $5 \mu \mathrm{g}$ of plasmid DNA containing either the EIa gene of $5 \mu \mathrm{g}$ of pJAM DNA, and $5 \mu \mathrm{g}$ of a plasmid DNA containing the $\beta$-globin promoter/ per $100-\mathrm{mm}$ dish of cells at $60 \%$ confluency. Cells were washed and harvested in ice-cold phosphate-buffered saline (PBS), collected by centrifugation, and resuspended in $25 \mathrm{~mm}$ Tris- $\mathrm{HCl}$ buffer $(\mathrm{pH} 7.5)$. The cell suspension (derived from two plates) was divided in half: Onehalf was used for the preparation of RNA to determine the amount of $\beta$-globin mRNA present (analyzed as described by Costa et al. 1986); the other half of the cell suspension was lysed by three cycles of freezing and thawing. Soluble extract was prepared and assayed for CAT activity using ${ }^{3} \mathrm{H}$-labeled acetyl-coenzyme $\mathrm{A}(1.4 \mathrm{Ci} / \mathrm{mmole})$ and chloramphenicol as described previously (Sleigh 1986).

\section{Acknowledgments}

We wish to thank Dr. Lynne Vales for helpful discussion, reading the manuscript, and helping us with the transfection experiments. We also thank Drs. K.J. Marians, M. Inouye, and R. Weinmann for reading the manuscript; Drs. P. Deutsch and J.F. Habener for providing us with plasmid DNAs containing the somatostatin and gonadotropin promoters, and Dr. R. Costa and Dr. J. Darnell for providing us with the plasmid DNA containing the $\beta$-globin gene. We also thank Mr. O. Flores, Dr. S. Lobos, and Mr. J. Carcamo from our laboratory for providing us with the general transcription factors. The expertise of Dr. NaiSheng Lin in preparing the nuclear extracts is acknowledged. We also thank the members of the laboratory for active discussions. This work was supported by grants from the National Institutes of Health (GM-37120), the New Jersey Commission on Cancer Research (grant 687-035), the Foundation of the University of Medicine and Dentistry of New Jersey to D.R., and a grant from the National Cancer Institute (28146) to P.H. D.R. was also the recipient of an American Cancer Society Junior Faculty Research Award (JFRA-205).

\section{References}

Allan, M., J. Zhu, P. Montague, and J. Paul. 1984. Differential response of multiple epsilon globin cap sites to cis- and trans-acting controls. Cell 38: 399-407.

Berk, A.J. 1986. Adenovirus promoters and E1A transactivation. Annu. Rev. Genet. 20: 45-79.

Berk, A.J. and P.A. Sharp. 1978. Structure of the adenovirus 2 early mRNAs. Cell 14: 695-711.

Breathnach, R. and P. Chambon. 1981. Organization and expression of eukaryotic split genes coding for proteins. Annu. Rev. Biochem. 50: 349-393.
Briggs, M.R., J.T. Kadonaga, S.P. Bell, and R. Tjian. 1986. Purification and biochemical characterization of the promoterspecific transcription factor SP1. Science 234: 47-52.

Chow, L.T., T.R. Broker, and J.B. Lewis. 1979. Complex splicing patterns of RNAs from the early regions of adenovirus $2 . J$. Mol. Biol. 134: 265-304.

Costa, R.H., E. Lai, and J.E. Darnell, Jr. 1986. Transcriptional control of the mouse prealbumin (transthyretin) gene: Both promoter sequences and a distinct enhancer are cell specific. Mol. Cell. Biol. 6: 4697-4708.

Deutsch, P., J.L. Janeson, and J.F. Habener. 1987. Cyclic AMP responsiveness of human gonadotropin-alpha gene transcription is directed by a repeated 18 base pair enhancer. $J$. Biol. Chem. 262: 12169-12174.

Dignam, D.J., R.M. Lebovitz, and R.G. Roeder. 1983. Accurate transcription initiation by RNA polymerase II in a soluble extract from isolated mammalian nuclei. Nucleic Acids Res. 11: $1475-1485$.

Dorn, A., J. Bollekens, A. Staub, C. Benoist, and D. Mathis. 1987. A multiplicity of CCAAT box-binding proteins. Cell 50: $863-872$.

Dynan, W.S. and R. Tjian. 1983. Isolation of transcription factors that discriminate between different promoters recognized by RNA polymerase II. Cell 32: 669-680.

1983. The promoter-specific transcription factor Spl binds to upstream sequences in the SV40 early promoter. Cell 35: 79-87.

- 1985. Control of eukaryotic mRNA synthesis by sequence-specific DNA binding proteins. Nature 316: 774778.

Gilardi, P. and M. Perricaudet. 1984. The E4 transcriptional unit of Ad2: Far upstream sequences are required for its transactivation by E1A. Nucleic Acids Res. 12: 7877-7888.

. 1986. The E4 promoter of adenovirus type 2 contains an ElA dependent cis-acting element. Nucleic Acids Res. 14: 9035-9049.

Green, M.R., R. Treisman, and T. Maniatis. 1983. Transcriptional activation of cloned human beta-globin genes by viral immediate-early gene products. Cell 35: 137-145.

Hager, D.A. and R.R. Burgess. 1980. Elution of proteins from SDS-polyacrylamide gels, removal of SDS, and renaturation of enzyme activity: Results with sigma subunit of $E$. coli RNA polymerase, wheat germ DNA topoisomerase, and other enzymes. Anal. Biochem. 109: 76-86.

Hanaka, S., J. Nishigaki, P.A. Sharp, and H. Handa. 1987. Regulation of in vitro and in vivo transcription of early-region IV of adenovirus type 5 by multiple cis-acting elements. Mol. Cell. Biol. 7: 2578-2587.

Handa, H. and P.A. Sharp. 1984. Requirement for distal upstream sequences for maximal transcription in vitro of early region IV of adenovirus. Mol. Cell. Biol. 4: 791-798.

Hearing, P. and T. Shenk. 1983. The adenovirus type 5 E1A transcriptional control region contains a duplicated enhancer element. Cell 33: 695-703.

Hurst, H.C. and N.C. Jones. 1988. Identification of factors that interact with the E1A-inducible adenovirus E3 promoter. Genes Dev. 1: 1132-1146.

Kadonaga, J.T. and R. Tjian. 1986. Affinity purification of sequence-specific DNA binding proteins. Proc. Natl. Acad. Sci. 83: 5889-5893.

Kao, H.T. and J.R. Nevins. 1983. Transcriptional activation and subsequenct control of the human heat shock gene during adenovirus infection. Mol. Cell. Biol. 3: 2058-2065.

Kasher, M.S., P. Pintel, and D.C. Ward. 1986. Rapid enrichment of HeLa transcription factors IIIB and IIIC by using affinity chromatography based on avidin-biotin interactions. Mol. 
Cell. Biol. 6: 3117-3127.

Khoury, G. and P. Gruss. 1983. Enhancer elements. Cell 33: $313-314$.

Kovesdi, I., R. Reichel, and J.R. Nevins. 1986. Identification of a cellular transcription factor involved in E1A trans-activation. Cell 45: 219-228.

Lee, K.A.W. and M.R. Green. 1987. A cellular transcription factor E4Fl interacts with an E1A inducible enhancer and mediates constitutive enhancer function in vitro. EMBO J. 6: $1345-1353$.

Lee, W., P. Mitchell, and R. Tiian. 1987. Purified transcription factor Ap-1 interacts with TPA inducible enhancer elements. Cell 49: 741-752.

Leza, A. and P. Hearing. 1988. A cellular transcription factor binds to adenovirus early region promoters and to a cyclic AMP response element. J. Virol. (in press).

McKnight, S. and R. Tjian. 1987. Transcriptional selectivity of viral genes in mammalian cells. Cell 46: 795-805.

Montminy, M.R. and L.M. Bilezikjian. 1987. Binding of a nuclear protein to the cyclic-AMP response element of the somatostatin gene. Nature 328: 175-178.

Montminy, M.R., K.A. Sevarino, J.A. Wagner, G. Mandel, and H.M. Goodman. 1986. Identification of a cyclic-AMP responsive element within the rat somatostatin gene. Proc. Natl. Acad. Sci. 83: 6682-6686.

Nasmyth, K., D. Stillman, and D. Kipling. 1987. Both positive and negative regulators of $\mathrm{HO}$ transcription are required for mother-cell-specific mating type switching in yeast. Cell 48: $579-587$.

Nevins, J.R. 1981. Mechanism of activation of early viral transcription by the adenovirus E1A gene product. Cell 26: $213-$ 220.

Perricaudet, M., G. Akusjarvi, A. Virtamen, and U. Peterson. 1979. Structure of two spliced mRNAs from the transforming region of human subgroup $\mathrm{C}$ adenoviruses. Nature 281: 694-696.

Reinberg, D. and R.G. Roeder. 1987. Factors involved in specific transcription by mammalian RNA polymerase II. $/$. Biol. Chem. 262: 3310-3321.

Reinberg, D., M. Horikoshi, and R.G. Roeder. 1987. Factors involved in specific transcription in mammalian RNA polymerase II. J. Biol. Chem. 262: 3322-3330.

Rosales, R., M. Vigeneron, M. Macchi, I. Davidson, J.H. Xiao, and P. Chambon. 1987. In vitro binding of cell-specific and ubiquitous nuclear proteins to the octamer motif of the SV40 enhancer and related motifs present in other promoters and enhancers. EMBO I. 6: 3015-3023.

Sawadogo, M. and R.G. Roeder. 1985. Interaction of a gene-specific transcription factor with the adenovirus major late promoter upstream of the TATA box region. Cell 43: 165-175.

Schule, R., M. Muller, H. Otsuka-Murakami, and R. Renkawitz. 1988. Cooperativity of the glucocorticoid receptor and the CACCC-box binding factor. Nature 332: 87-90.

Short, J.M., A. Wynshaw-Boris, H.P. Short, and R.W. Hanson. 1986. Characterization of the phosphoenolpyruvate carboxykinase (GTP) promoter-regulatory region. J. Biol. Chem. 261: 9721-9726.

Sleigh, M.J. 1986. A nonchromatographic assay for expression of the chloramphenicol acetyltransferase gene in eukaryotic cells. Anal. Biochem. 156: 251-256.

Stein, R. and E.B. Ziff. 1984. HeLa cell beta tubulin gene transcription is stimulated by adenovirus 5 in parallel with viral early genes by an Ela-dependent mechanism. Mol. Cell. Biol. 4: 2792-2801.

Svensson, C. and G. Akusjardi. 1984. Adenovirus 2 early region
1 A stimulates expression of both viral and cellular genes. EMBO I. 3: 789-794.

Wigler, M., S. Silverstein, L.S. Lee, A. Pellicer, Y.C. Cheng, and R. Axel. 1977. Transfer of purified herpes virus thymidine kinase gene to cultured mouse cells. Cell 11: 223-232.

Xiao, J.H., I. Davidson, D. Ferrandon, R. Rosales, M. Vigneron, M. Macchi, F. Ruffenach, and P. Chambon. 1987. One cellspecific and three ubiquitous nuclear proteins bind in vitro to overlapping motifs in the domain B1 of the SV40 enhancer. EMBO I. 6: 3005-3013. 


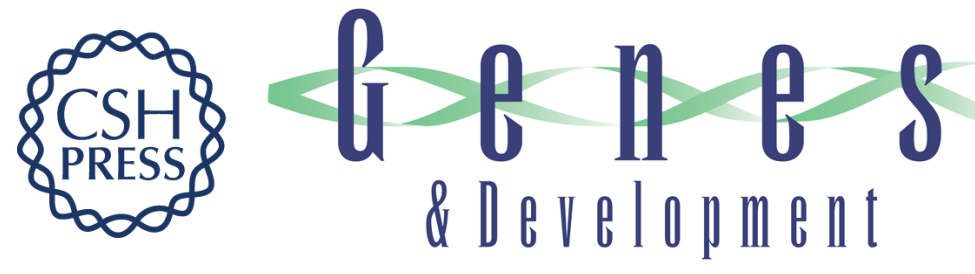

\section{EivF, a factor required for transcription of the adenovirus EIV promoter, binds to an element involved in Ela-dependent activation and CAMP induction.}

P Cortes, L Buckbinder, M A Leza, et al.

Genes Dev. 1988, 2:

Access the most recent version at doi:10.1101/gad.2.8.975

References This article cites 45 articles, 13 of which can be accessed free at: http://genesdev.cshlp.org/content/2/8/975.full.html\#ref-list-1

License

Email Alerting Service

Receive free email alerts when new articles cite this article - sign up in the box at the top right corner of the article or click here.

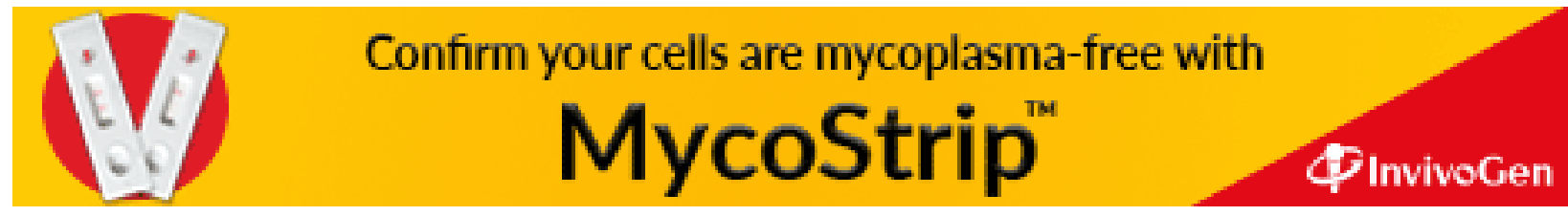

